OPEN ACCESS

Edited by:

Brian Dixon,

University of Waterloo,

Canada

Reviewed by:

Kevin R. Maisey,

Universidad de Santiago de Chile,

Chile

Francesco Buonocore, Università degli Studi della

Tuscia, Italy

*Correspondence:

Teruyuki Nakanishi

nakanishi.teruyuki@

nihon-u.ac.jp

Specialty section:

This article was submitted to

Comparative Immunology,

a section of the journal

Frontiers in Immunology

Received: 02 February 2018 Accepted: 28 May 2018

Published: 13 June 2018

Citation:

Miyazawa R, Murata N, Matsuura Y, Shibasaki Y, Yabu T and Nakanishi T

(2018) Peculiar Expression of CD3-Epsilon in Kidney of Ginbuna Crucian Carp.

Front. Immunol. 9:1321.

doi: 10.3389/fimmu.2018.01321

\section{Peculiar Expression of CD3-Epsilon in Kidney of Ginbuna Crucian Carp}

\author{
Ryuichiro Miyazawa ${ }^{1}$, Norifumi Murata ${ }^{1}$, Yuta Matsuura ${ }^{2}$, Yasuhiro Shibasaki ${ }^{3}$, \\ Takeshi Yabu ${ }^{4}$ and Teruyuki Nakanishi ${ }^{1 *}$ \\ ${ }^{1}$ Department of Veterinary Medicine, Nihon University, Fujisawa, Japan, ${ }^{2}$ Research Center for Fish Diseases, National \\ Research Institute of Aquaculture, Minami-ise, Japan, ${ }^{3}$ Department of Pathobiology, School of Veterinary Medicine, \\ University of Pennsylvania, Philadelphia, PA, United States, ${ }^{4}$ Department of Applied Biological Science, Nihon University, \\ Fujisawa, Japan
}

TCR/CD3 complex is composed of the disulfide-linked TCR- $\alpha \beta$ heterodimer that recog-

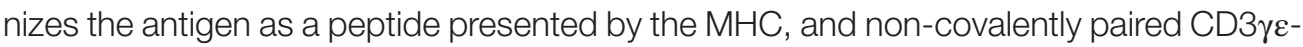
and $\delta \varepsilon$-chains together with disulfide-linked $\zeta$-chain homodimers. The CD3 chains play key roles in T cell development and T cell activation. In the present study, we found nor or extremely lower expression of CD3 $\varepsilon$ in head- and trunk-kidney lymphocytes by flow cytometric analysis, while CD3 $\varepsilon$ was expressed at the normal level in lymphocytes from thymus, spleen, intestine, gill, and peripheral blood. Furthermore, CD4-1+ and CD8 $\alpha^{+}$ T cells from kidney express Zap-70, but not CD3 $\varepsilon$, while the T cells from other tissues express both Zap-70 and CD3e, although expression of CD3 $\varepsilon$ was low. Quantitative analysis of mRNA expression revealed that the expression level of $T$ cell-related genes including tcrb, cd3e, zap-70, and Ick in CD4-1+ and CD8 $\alpha^{+}$T cells was not different between kidney and spleen. Western blot analysis showed that CD3 $\varepsilon$ band was detected in the cell lysates of spleen but not kidney. To be interested, CD3e-positive cells greatly increased after $24 \mathrm{~h}$ in in vitro culture of kidney leukocytes. Furthermore, expression of CD3 $\varepsilon$ in both transferred kidney and spleen leukocytes was not detected or very low in kidney, while both leukocytes expressed CD3 $\varepsilon$ at normal level in spleen when kidney and spleen leukocytes were injected into the isogeneic recipient. Lower expression of CD3 $\varepsilon$ was also found in kidney $T$ lymphocytes of goldfish and carp. These results indicate that kidney lymphocytes express no or lower level of CD3e protein in the kidney, although the mRNA of the gene was expressed. Here, we discuss this phenomenon from the point of function of kidney as reservoir for T lymphocytes in teleost, which lacks lymph node and bone marrow.

\section{Keywords: CD3-epsillon, CD4, CD8, kidney, teleost, ginbuna crucian carp, T lymphocytes}

\section{INTRODUCTION}

The antigen receptor complex on T-cell (TCR/CD3) consists of the disulfide-linked TCR- $\alpha \beta$ heterodimer that recognizes the antigen as a peptide presented by the MHC, and non-covalently paired $\mathrm{CD} 3 \gamma \varepsilon$ - and $\delta \varepsilon$-chains together with disulfide-linked $\zeta$-chain homodimers. In mice and humans, CD3 $\varepsilon$ and $\zeta$ chains as well as TCR $\alpha$ and $\beta$ chains are essential for surface expression of TCR/CD3 complex, while CD3 $\delta$ and $\gamma$ chains are individually dispensable (1). Dynamic change of TCR/CD3 cell surface expression has been reported in resting and antigen-activated T cells (2). CD3 chains play 
critical roles in the various phases of thymocyte development. For instance, the removal of CD3r led to a complete impairment of

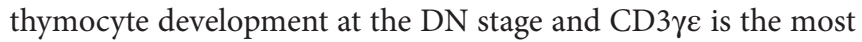
critical for DN-to-DP transition (3). The role of CD3 chains in mature $\mathrm{T}$ cell activation has been also reported $(4,5)$. Ahmadi et al. (6) showed that co-transfer of CD3 and TCR genes into primary murine $\mathrm{T}$ cells enhanced TCR expression and antigenspecific T-cell function in vitro. Further, they demonstrated that addition of CD3 protein is effective to enhance the avidity, antitumor activity, and functional memory formation of TCR gene-modified $\mathrm{T}$ cells in vivo. In contrast, downregulation in the expression of CD3 chains in T cells and impaired immune responses have been reported in patients with malignant and/or inflammatory autoimmune diseases (7-9). These reports indicate that the critical roles of $\mathrm{CD} 3$ chains in mature $\mathrm{T}$ cell activation as well as in $\mathrm{T}$ cell development and signaling.

Fish CD3 genes have been reported from chondrostean fish (sterlet) and teleost [e.g., Japanese flounder, fugu, Atlantic halibut, sea bass, Atlantic salmon, and common carp (10)]. CD3 transcripts were widely expressed in teleost tissues including lymphoid tissues (e.g., thymus, head- and trunk-kidney, and spleen), mucosal tissues (e.g., gill, skin, and intestine), and peripheral blood leukocytes (PBL) (10-14). Non-mammalian vertebrates including birds, amphibians, and teleost fish possess only three types of $\mathrm{CD} 3$, e.g., $\mathrm{CD} 3-\gamma \delta, \mathrm{CD} 3-\varepsilon$, and the $-\zeta$ chain with CD3$\gamma \delta$ reflecting the common ancestor of mammalian CD3- $\gamma$ and CD3- $\delta$ (15). The lack of interaction between chicken TCR $\alpha \beta$ heterodimers and the human CD3 complex has been reported (16). Furthermore, there exist significant differences in the relative functions of the various CD3 chains even between mice and humans (17). In fish, however, function of CD3 chains, particularly, the role in the expression of TCR/CD3 complex remains unknown.

The obvious differences between fish and mammals are that fish lack a bone marrow and lymph nodes, and instead, the kidney is a major lymphoid organ in the teleost in addition to the thymus, spleen, and mucosa-associated lymphoid tissues (18). Teleost kidney is considered to be homologous organ to the bone marrow and lymph node in mammals (19). It has been reported that the presence of hematopoietic stem cells in the kidney of ginbuna and zebrafish $(20,21)$. Abundant presence of immature leukocytes or blast cells in the kidney of teleost also suggests that teleost kidney is equivalent to the bone marrow of mammals. It is well known in mammals that interactions between $\mathrm{T}$ cells and dendritic cells in the lymph nodes are crucial for initiating cell-mediated adaptive immune responses $(22,23)$ and the germinal centers are main sites for $\mathrm{T}$ cell-dependent immune responses (24). In fish, however, information on the tissues or sites equivalent to lymph nodes and germinal centers is limited.

In the present study, we found that CD4-1+ and CD $8 \alpha^{+}$ $\mathrm{T}$ lymphocytes from head-and trunk-kidney express Zap-70, but not $\mathrm{CD} 3 \varepsilon$, while $\mathrm{T}$ lymphocytes from tissues except kidney express both $\mathrm{CD} 3 \varepsilon$ and Zap-70. Interestingly enough, T lymphocytes from the head- and trunk-kidney become positive for the expression of $\mathrm{CD} 3 \varepsilon$ after $24 \mathrm{~h}$ in in vitro culture. Furthermore, expression of $\mathrm{CD} 3 \varepsilon$ in kidney leukocytes became positive when kidney leukocytes were injected into the isogeneic recipient and migrated into spleen. These results indicate that expression of $\mathrm{CD} 3 \varepsilon$ molecule was suppressed in the kidney. Here, we discuss this phenomenon from the point of function of kidney as reservoir for T lymphocytes in teleost, which lacks lymph node and bone marrow.

\section{MATERIALS AND METHODS}

\section{Experimental Fish}

Triploid female ginbuna crucian carp (Carassius auratus langsdorfii) from Okushiri Island in Hokkaido (OB1 clone) weighing 20-30 g were used for the experiment. Offspring of OB1 clone were reproduced by naturally occurring gynogenesis artificially inseminated with loach sperm and were maintained in tanks with running water at $25 \pm 1^{\circ} \mathrm{C}$ and fed twice daily with commercial pellets throughout the experiments.

\section{Identification and Characterization of Ginbuna CD3ع}

To obtain the partial ginbuna $\mathrm{CD} 3 \varepsilon$ nucleotide sequences, we performed RT-PCR using primers (Table 1) designed using nucleotide sequence of zebrafish $c d 3 e$ (NM_001326401) and Japanese flounder $c d 3 e$ (AB081751). PCR was carried out in $40-\mu \mathrm{l}$ reaction mixtures containing Prime STAR HS, with reaction conditions consisting of denaturation at $96^{\circ} \mathrm{C}$ for 2 min and 30 cycles of denaturation at $94^{\circ} \mathrm{C}$ for $10 \mathrm{~s}$, annealing at $60^{\circ} \mathrm{C}$ for $10 \mathrm{~s}$, polymerization at $72^{\circ} \mathrm{C}$ for $30 \mathrm{~s}$, and extension at $72^{\circ} \mathrm{C}$ for $2 \mathrm{~min}$. The PCR products were subcloned into the pGEM-T Easy plasmid vector by using a TA-Cloning method (Promega, Madison, WI, USA). After confirming through sequencing, 5'RACE and $3^{\prime}$-RACE protocols (TaKaRa Bio, Shiga, Japan) were used to obtain full-length gCD $\varepsilon \varepsilon$ sequences using the primers in Table 1. Nucleotide and amino acid sequence were analyzed using GENETYX-WIN version 9.0 and CLUSTALW. Similarity searches were performed using BLAST against the NCBI nonredundant protein database and the Protein Data Bank. Ig domains, CXXC motif, and immunoreceptor tyrosine-based activation motifs (ITAM) were predicted using Simple Modular Architecture Research Tool. Phylogenetic analysis was performed using molecular evolutionary genetics analysis.

\section{Recombinant Protein Production}

The cDNA sequences of ginbuna $c d 3 e$ were amplified and subcloned into a pET-16b vector (Novagen, Madison, WI, USA). To increase solubility, transmembrane (TM) domain was deleted within $\mathrm{CD} 3 \varepsilon$ sequence and named as $\mathrm{CD} 3 \mathrm{e}-\Delta \mathrm{TM}$. The CD3e$\Delta \mathrm{TM}$ plasmid DNA was amplified using the primers (gCD3edel-TM-F, gCD3e-del-TM-R in Table 1) phosphorylated with Prime STAR mutagenesis kit (TaKaRa Bio, Shiga, Japan). The construct was designated as pET-CD3e- $-\mathrm{TM}$. The CD3e $-\Delta \mathrm{TM}$ protein was expressed in Escherichia coli BL21 (DE3) pLysS cells (Novagen) that had been transformed with pET-CD3e- $\Delta$ TM. After the three chromatography purification steps, sequential His-tag affinity purification, gel filtration chromatography, and endotoxin removal, the recombinant proteins were used for immunization of rabbit. 
TABLE 1 | Oligonucleotide primers used in this study.

\begin{tabular}{|c|c|c|c|}
\hline Primer name & Sequence $\left(5^{\prime} \rightarrow 3^{\prime}\right)$ & & GenBank accession number \\
\hline \multicolumn{4}{|l|}{ cDNA cloning } \\
\hline $\operatorname{gcd} 3 e \mathrm{~F} 1$ & GAAGCCGGAAAAGATGTCAG & 3'RACE & \\
\hline gcd3eF2 & CAGTGAAACCGAAGAACAGC & 3'RACE & \\
\hline $\operatorname{gcd} 3 e \mathrm{R} 1$ & GGTाTGGGGGACGAGGAG & 5'RACE & \\
\hline gcd3eR2 & TCTCATAGTCCGGGTITGG & 5'RACE & \\
\hline gcd3eR3 & GAGTCTGAGTGTTCAGTITCTCATA & 5'RACE & \\
\hline gcd3e-CDS F & TGTCTTCAGGACGATACAGAACC & CDS & \\
\hline gcd3e-CDS R & CCCTATGAATCACCAGAGTITGA & CDS & \\
\hline gcd3e-del-TM-F & TGTTCTGCCAGAAACAGTGACAGCAAACC & TM deletion & \\
\hline gcd3e-del-TM-R & TCCGCTCAACTCATAGCAGTTCTCACAC & TM deletion & \\
\hline \multicolumn{4}{|c|}{ Eukaryotic expression } \\
\hline gcd3e-rec F & $\begin{array}{l}\text { CATATGATCTGCACTGGAGGAGACAATAGG } \\
\text { GTAG }\end{array}$ & Recombinant protein & \\
\hline gcd3e-rec R & $\begin{array}{l}\text { CATATGCTACTTATTGAGGCCTGCGTACAAC } \\
\text { CCATC }\end{array}$ & Recombinant protein & \\
\hline \multicolumn{4}{|c|}{ Expression analysis } \\
\hline gef1 $\alpha \mathrm{F}$ & ACCCCAAGGCTCTCAATCT & qPCR & AB491676 \\
\hline$g e f 1 \alpha R$ & TCAACGCTCTTGATGACACC & qPCR & \\
\hline gcd3eF & CTGCTATGAGTTGAGCGGAGTGAT & qPCR & LC378416 \\
\hline gcd3eR & CTTCGGTTTGCTGTCACTGTITCT & qPCR & \\
\hline gtcrbF & CCTGAAGCCСTCTGAAATCG & qPCR & AB186399 \\
\hline gtcrbR & TGCTTCCAAGGCTCCATCTT & qPCR & \\
\hline gzap70F & TCCGAGAGAGAGAAGAATITGGA & qPCR & \\
\hline gzap70R & СATTGCGTATTTCCCTGATTTGT & qPCR & \\
\hline glckF & CCATCCAGTCAAATACAGCAAA & qPCR & AB279594 \\
\hline glckR & СТTCTCAAACCCAAGGTCATC & qPCR & \\
\hline \multicolumn{4}{|c|}{ In situ hybridization (ISH) } \\
\hline gcd3e probe-t7 & $\begin{array}{l}\text { TAATACGACTCACTATAGGGGATGTCAGTG } \\
\text { GAGAAGGAAA }\end{array}$ & $\mathrm{ISH}$ & \\
\hline gcd3e probe-sp6 & $\begin{array}{l}\text { ATTAGGTGACACTATAGAAGTCATGTATA } \\
\text { TCTCTCAGTG }\end{array}$ & ISH & \\
\hline
\end{tabular}

\section{Production of Polyclonal Antibody}

New Zealand White rabbit were immunized with the purified recombinant $\mathrm{CD} 3 \varepsilon$ according to the standard method. Rabbits were bled by cardiac puncture under deep terminal anesthesia and the serum were purified by protein $G$ sepharose (GE Healthcare, Piscataway, NJ, USA) according to the manufacturer's protocols and guidelines. The antibody was further purified by an affinity column, which was prepared by coupling of recombinant CD3e- $\Delta$ TM protein to NHS-activated Sepharose (GE Healthcare, Piscataway, NJ, USA) according to the manufacturer's instructions.

\section{Preparation of Leukocytes}

Fish were deeply anesthetized with $35 \mathrm{ppm}$ ethyl-4-aminobenzoate (Benzocaine, Sigma-Aldrich, St. Louis, MO, USA), and their spinal cords were severed for euthanasia. Fish were bled from the caudal blood vessels with a heparinized syringe, and the thymus, spleen, head-kidney, trunk-kidney, gill, and intestine were dissected. To avoid contamination with blood, $10 \mathrm{ml}$ of PBS with $10 \mathrm{U} / \mathrm{ml}$ of heparin (Wako Chemicals, Osaka, Japan) was injected into gill tissue through the bulbus arteriosus. All subsequent manipulations of cells were done at $4^{\circ} \mathrm{C}$.

For the thymus, spleen, head-kidney, and trunk-kidney, the organs were placed on a stainless steel mesh filter $(100 \mu \mathrm{m})$ and pressed through with $5 \mathrm{ml}$ of HBSS (Nissui Pharmaceutical Co. Ltd., Tokyo, Japan) to create single-cell suspensions. For gill and intestine, the tissues were incubated with PBS containing $1 \mathrm{mM}$ DTT (Wako Chemicals, Osaka, Japan) and $1 \mathrm{mM}$ EDTA for 15 min after mincing with scissors. After incubation, the organs were washed and dissociated by incubating with calcium- and magnesium-free Hank's Balanced Salt Solution (CMF-HBSS) containing $0.1 \mathrm{mg} / \mathrm{ml}$ collagenase (Wako Chemicals, Osaka, Japan), $0.1 \mathrm{mg} / \mathrm{ml}$ DNase (Sigma-Aldrich, St. Louis, MO, USA), and 5\% FBS for 90 min with shaking at room temperature. Dissociated organs were disaggregated by pressing through the stainless steel mesh filter into HBSS. The buffy coat from peripheral blood and leukocytes from tissues were collected by centrifugation at $400 \times g$ for $5 \mathrm{~min}$ at $4^{\circ} \mathrm{C}$. After discarding the supernatant, $1 \mathrm{ml}$ of distilled water was added to cell pellet and gently mixed with a pipette to lyse mature erythrocytes. Subsequently, $9 \mathrm{ml}$ of the $0.2 \%$ FBS-HBSS was added and the cells were washed twice by centrifugation. Cell concentration and viability were determined by trypan blue dye exclusion with a hemocytometer. Viability of cells was approximately $90 \%$.

\section{Cell Culture}

Head- and trunk-kidney lymphocyte were suspended in RPMI1640 medium (Thermo Fisher Scientific Inc., MA, USA) 
supplemented with $1 \%$ ginbuna serum. The cells were seeded in 6 -well plates at $1 \times 10^{6}$ cells $/ 2 \mathrm{ml} /$ well at $25^{\circ} \mathrm{C}$ with $5 \% \mathrm{CO}_{2}$ for $24 \mathrm{~h}$.

\section{Flow Cytometry}

$5 \times 10^{6}$ cells $/ \mathrm{ml}$ of leukocytes from the various tissues were fixed with $2 \%$ paraformaldehyde (PFA) followed by cell membrane permeabilization with $0.1 \%$ saponin for $10 \mathrm{~min}$. Cells were then incubated with 1:300 anti-gCD3 $\varepsilon$ antibody or Rabbi (DA1E) $\mathrm{mAb}$ IgG Isotype control (CST, MA, USA) for $45 \mathrm{~min}$ at $4^{\circ} \mathrm{C}$, washed three times, and stained with 1:500 diluted Alexa Fluor ${ }^{\circledR} 647$ conjugated secondary antibody (Thermo Fisher Scientific Inc., MA, USA) against anti-gCD3 $\varepsilon$ antibody. The cells were then washed three times and served for flow cytometric analysis. Lymphocytes were gated on FS and SS dot plot and then analyzed using a FACS Canto flow cytometer (Becton Dickinson, NJ, USA).

For two-color immunofluorescence analysis of cell surface antigens along with $\mathrm{T}$ cell-specific intracellular markers including Zap-70 and $\mathrm{CD} 3 \varepsilon$, kidney leukocytes were first incubated with $m$ Abs against CD4-1(6D1, rat), CD8 $\alpha$ (2C3, rat), IgM (B12, mouse), phagocyte (GB21, mouse), and thrombocyte (GB10, mouse) markers and then fixed with $2 \%$ PFA followed by cell membrane permeabilization with $0.1 \%$ saponin for $10 \mathrm{~min}$. Cells were then incubated with 1:300 anti-gCD3 $\varepsilon$ antibody or 1:50 anti-hZap-70 (rabbit, CST, MA, USA) for $45 \mathrm{~min}$ at $4^{\circ} \mathrm{C}$, washed three times, and stained with 1:500 diluted Alexa Fluor ${ }^{\circledR} 488$ donkey Anti-Rat IgG $(\mathrm{H}+\mathrm{L})$ antibody, Alexa Fluor ${ }^{\circledR} 488$ goat Anti-mouse IgG $(\mathrm{H}+\mathrm{L})$ antibody, and Alexa Fluor ${ }^{\circledR} 647$ goat Anti-rabbit IgG $(\mathrm{H}+\mathrm{L})$ antibody (Thermo Fisher Scientific Inc., MA, USA). A donkey anti-rat IgG antibody was used for mAbs $2 \mathrm{C} 3$ and $6 \mathrm{D} 1$, a goat anti-mouse IgG antibody was used for $\mathrm{mAbs}$ B12, GB21, and GB10 along with a goat anti-rabbit IgG antibody was used for mAbs gCD3e and hZap-70. The cells were then washed three times. Lymphocytes were gated on FS and SS dot plot and lymphocytes were then analyzed for double staining with the mAbs. Doublets discrimination was performed in FSA-H/ FSA-W and SSC-H/SSC-W dot plots with Flowjo 7 (TreeStar).

\section{Transcriptional Analysis of FACS Sorted Populations}

Leukocytes from kidney and spleen were labeled with mAbs against CD4-1 and CD $8 \alpha$ as described above. Dead cells were eliminated by $2.5 \mu \mathrm{g} / \mathrm{ml}$ of propidium iodide (Thermo Fisher Scientific Inc., MA, USA). Lymphocyte fraction of kidney and spleen leukocytes was gated and doublets discrimination was performed as described above. CD4- $1^{+}$and $\mathrm{CD} 8 \alpha^{+}$cells were isolated by FACS Aria II cell sorter (Becton Dickinson, NJ, USA). Purities of FACS sorted CD4-1 and CD8 $\alpha$ were confirmed to be more than $95 \%$ when the sorted lymphocytes were re-analyzed with the mAbs used for sorting by FACS analysis. Total RNA was extracted from $5 \times 10^{5}$ cells of FACS sorted cells using the ReliaPrep RNA Tissue Miniprep System (Promega, Madison, WI, USA) according to the manufacturer's protocols and guidelines. cDNA was synthesized from total RNA from each sample using a High-Capacity cDNA Reverse Transcription Kit (Applied Biosystems, CA, USA) according to the manufacturer's protocols and guidelines. mRNA expression analysis was performed by Real-time PCR using a Thermal Cycler Dice ${ }^{\circledR}$ Real Time System (TaKaRa Bio, Shiga, Japan). PCR reactions were performed with $5 \mu \mathrm{l}$ of 1:50 diluted cDNA, $12.5 \mu \mathrm{l}$ of SYBR ${ }^{\circledR}$ Premix Ex Taq (TaKaRa Bio, Shiga, Japan), and $200 \mathrm{nM}$ of each specific primer pair (Table 1) in $25 \mu \mathrm{l}$ mixtures under the following conditions: one cycle at $95^{\circ} \mathrm{C}$ for $30 \mathrm{~s}, 45$ cycles at $95^{\circ} \mathrm{C}$ for $5 \mathrm{~s}, 60^{\circ} \mathrm{C}$ for $30 \mathrm{~s}$. Melting curve analysis showed that there was no primer dimer formation.

Target genes were amplified on the same plate with the internal control genes, ef1a or T cell control gene, $l c k$, and the relative mRNA quantities were determined. Raw data were analyzed by the $2^{-\Delta \Delta \mathrm{CT}}$ method (25) normalized to ef1a or $l c k$.

\section{Transfer of Kidney and Spleen Leukocytes Into Isogeneic Recipient}

Kidney and spleen leukocytes of donor fish were prepared as mentioned above and were labeled with CFSE (Invitrogen) for detection by flow cytometry according to Toda et al. (26). Cell suspensions were adjusted to $2 \times 10^{6}$ cells $/ \mathrm{ml}$ and labeled with $5 \mu \mathrm{M}$ CFSE (invitrogen) for $10 \mathrm{~min}$ at room temperature. The reaction was stopped by the addition of an equal volume of HBSS at $4^{\circ} \mathrm{C}$ followed by three washes. $100 \mu \mathrm{l}$ of $5 \times 10^{7}$ cells $/ \mathrm{ml}$ of CFSE-stained kidney or spleen leukocytes were then injected into the naïve isogeneic recipient via caudal blood vein. Kidney and spleen cell suspension of recipient fish were prepared and the percentages of CFSE-positive cells were analyzed by FACS.

\section{Western Blot Analysis}

Leukocytes from kidney and spleen were lysed in $25 \mathrm{mM}$ Tris$\mathrm{HCl}$ (pH 7.4), $150 \mathrm{mM} \mathrm{NaCl}, 0.1 \%$ TritonX-100, 0.05\% SDS. The extracted proteins were resolved on a SDS-polyacrylamide gel and electroblotted onto a PVDF membrane as described by Yabu et al. (27). The Membrane was blocked with blocking reagent (Block-Ace, Dainippon Pharmaceutical Co., Ltd., Osaka, Japan) for $1 \mathrm{~h}$ at room temperature. The Membrane was probed with 1:300 Anti-gCD3e Ab overnight at $4^{\circ} \mathrm{C}$, washed five times, and incubated with horseradish peroxidase goat anti-rabbit IgG antibody (Sigma-Aldrich, St. Louis, MO, USA) diluted 1:10,000 for $1 \mathrm{~h}$ at room temperature, and washed an additional five times. Membranes were visualized by Western Lightning ECL Pro (Perkin Elmer, Inc., Waltham, MA, USA) and exposed to Hyperfilm ECL (GE Healthcare, Piscataway, NJ, USA).

\section{Immunohistological Analysis}

Cryosections ( $8 \mu \mathrm{m}$ ) were prepared as previously reported (28). For immuno-staining, frozen sections were incubated with 1:300 diluted rabbit anti-CD3e Ab or Rabbi (DA1E) mAbIgG Isotype control (CST, MA, USA) for $8 \mathrm{~h}$ at $4^{\circ} \mathrm{C}$, washed, and then stained with 1:500 diluted Alexa Fluor ${ }^{\circledR} 488$ goat Anti-rabbit IgG $(\mathrm{H}+\mathrm{L})$ antibody as a secondary antibody. Sections were then washed three times and nuclei were stained with DAPI (Sigma-Aldrich, St. Louis, MO, USA). Finally, the sections were mounted with ProLong Gold anti-fade mounting medium (Life Technologies). Sections were examined by fluorescence microscopy (Olympus IX71) with a digital camera and software (Olympus DP73). 


\section{In situ Hybridization (ISH)}

A 1,295-bp of gCD $\varepsilon$ cDNA was subcloned into the pGEM-T Easy plasmid vector and then appended T7 and SP6 promoter sequence at the $5^{\prime}$ and $3^{\prime}$ terminal, respectively, by PCR reaction using primers (Table 1). The PCR product was used for sense and antisense RNA probe synthesized using DIG RNA Labeling Kit (SigmaAldrich, St. Louis, MO, USA). For the ISH of tissue sections, tissue samples from kidney, spleen, and thymus were fixed at $4^{\circ} \mathrm{C}$ for $12 \mathrm{~h}$ in $4 \%$ PFA. Cryosections $(7 \mu \mathrm{m})$ were prepared on the slide. ISH was performed as described previously by Nagasawa et al. (29). The sections were then incubated in $0.0018 \%$ of BCIP (SigmaAldrich, St. Louis, MO, USA) and a NTMT solution containing $0.0035 \%$ of NBT (Nacalai tesque, Japan) at RT in the dark. After the color reaction had occurred, sections were washed with PBS. Finally, the sections were mounted with $70 \%$ glycerol. Sections were examined under BX51 microscope (Olympus, Tokyo, Japan).

\section{Statistics}

Results of FCM analysis were statistically compared using twoway ANOVAs, followed by Tukey's multiple comparisons tests to detect significant difference between means in the percentage of positive cells. A $p$ value of $<0.05$ was considered statistically significant.

\section{RESULTS}

\section{Ginbuna CD3 $\varepsilon$ Sequence Analysis}

Sequence analysis of $5^{\prime}$ RACE and $3^{\prime}$ RACE PCR product revealed that ginbuna $\mathrm{CD} 3 \varepsilon \mathrm{cDNA}$ consists of 1,499 nucleotides with a 519 bp open reading frame encoding 173 amino acid (Figure S1A in Supplementary Material). Comparison of gCD3 $\varepsilon$ with Atlantic salmon CD3e (NM_001123622) and human CD3e (NM_000733.3) revealed that the polypeptide was composed of a signal peptide sequence, CXXC motif, a Ig-like domain containing two Ig-fold cysteine, and ITAM in cytoplasmic domain (Figures S1B,C in Supplementary Material). These data indicate that $\mathrm{gCD} 3 \varepsilon$ has similar feature to that of other vertebrate $\mathrm{CD} 3 \varepsilon$. Phylogenetic analysis revealed that $\mathrm{gCD} 3 \varepsilon$ was classified into the vertebrate $\mathrm{CD} 3 \varepsilon$ group (Figure S1D in Supplementary Material).

\section{Specificity of Antibody Against Ginbuna CD3e}

Specificity of rabbit antibody purified with antigen column using recombinant ginbuna $\mathrm{CD} 3 \varepsilon(\mathrm{rgCD} 3 \varepsilon)$ was examined. Western blot analysis showed that the antibody is specific to native ginbuna $\mathrm{CD} 3 \varepsilon(\mathrm{gCD} 3 \varepsilon)$ present in thymus and spleen since positive band was detected at $20-25 \mathrm{kDa}$ as expected molecular weight (Figure S2 in Supplementary Material) and disappeared after adsorption with the $\operatorname{rgCD} 3 \varepsilon$ (Figure S3 in Supplementary Material). Immuno-precipitation followed protein sequencing by LC-MS/MS revealed that the antibody recognized gCD3 $\varepsilon$ (Figure S4 in Supplementary Material).

\section{CD4-1+ and CD8 $\alpha^{+}$Kidney Lymphocytes Express Zap-70, but not CD3ع}

In the present study, we found the expression of $\mathrm{CD} 3 \varepsilon$ in the lymphocytes from thymus, spleen, intestine, gill, and peripheral blood lymphocytes but not in the lymphocytes of head- and trunk-kidney where CD4-1 and CD8 $\alpha$ positive T cells were present (Figure 1). Immuno-histochemical analysis also showed that CD3e-positive cells are present in all of tissues examined except kidney and the morphology of antibody-positive cells showed the typical feature of lymphocyte (Figure 2).

We previously reported the distribution of CD4-1 and CD $8 \alpha$ positive lymphocytes in both lymphoid and non-lymphoid tissues of adult fish $(30,31)$. Present dual immune-fluorescence analysis revealed that CD4-1 and CD8 $\alpha$ positive lymphocytes in the head- and trunk-kidney did not express CD3e, while CD3 $\varepsilon$ expression was observed in other tissues, e.g., the thymus, spleen, gill, intestine, and peripheral blood (Figure 3). However, expression of Zap-70 was found in all tissues including head- and trunk-kidney. Majority of CD4-1 and CD8 $\alpha$ positive lymphocytes express lower level of both CD3E and Zap-70 in the thymus. Similar phenomenon was also observed in the spleen and PBL, although the tendency was more apparent in the thymus than spleen and PBL.

\section{FACS Sorted CD4-1+ and CD8 $\alpha^{+}$ Lymphocytes Express Transcripts of T Cell-Related Markers}

Since we found that CD4-1 $1^{+}$and $\mathrm{CD} 8 \alpha^{+}$kidney lymphocytes did not show the expression of CD3 $\varepsilon$ protein, we then examined the expression of CD3 $\varepsilon$ at mRNA level. All T cell-related genes including $t c r b, c d 3 \varepsilon, z a p-70$, and $l c k$ were expressed to the similar extent in both kidney and spleen (Figure 4).

\section{Expression of CD3e mRNA in Kidney as Well as Thymus and Spleen}

We confirmed the expression of CD3E mRNA in kidney as well as thymus and spleen by ISH (Figure 5). CD3 $\varepsilon$ mRNA positive cells were detected as small lymphocytes in the intertubular tissue of trunk-kidney (Figure 5C), although the number of positive cells in kidney was fewer when compared to thymus where most of cells were positive (Figure 5A).

\section{Presence of CD3e Protein in Spleen but not Kidney Leukocytes}

We further examined the expression of $\mathrm{CD} 3 \varepsilon$ protein in kidney and detected a clear band of $20 \mathrm{kDa}$ in spleen but not in kidney by Western Blot analysis (Figure 6). No band was detected even at higher dose of samples of kidney.

\section{Increased Expression of CD3 $\varepsilon$ Gene in Kidney Leukocytes After In Vitro Culture}

FACS analysis revealed that kidney leukocytes become positive for the expression of CD3E after $24 \mathrm{~h}$ in vitro culture (Figure 7A). The number of CD3E-positive cells was approximately 20 folds after the culture compared to that of leukocytes before the culture, although Zap-70-positive cells also two and three times increased (Figure 7B). However, mRNA expression of $c d 3 e$ normalized to $\mathrm{T}$ cell control gene, $l c k$ was not different in cells before and after the culture (Figure 7C). 


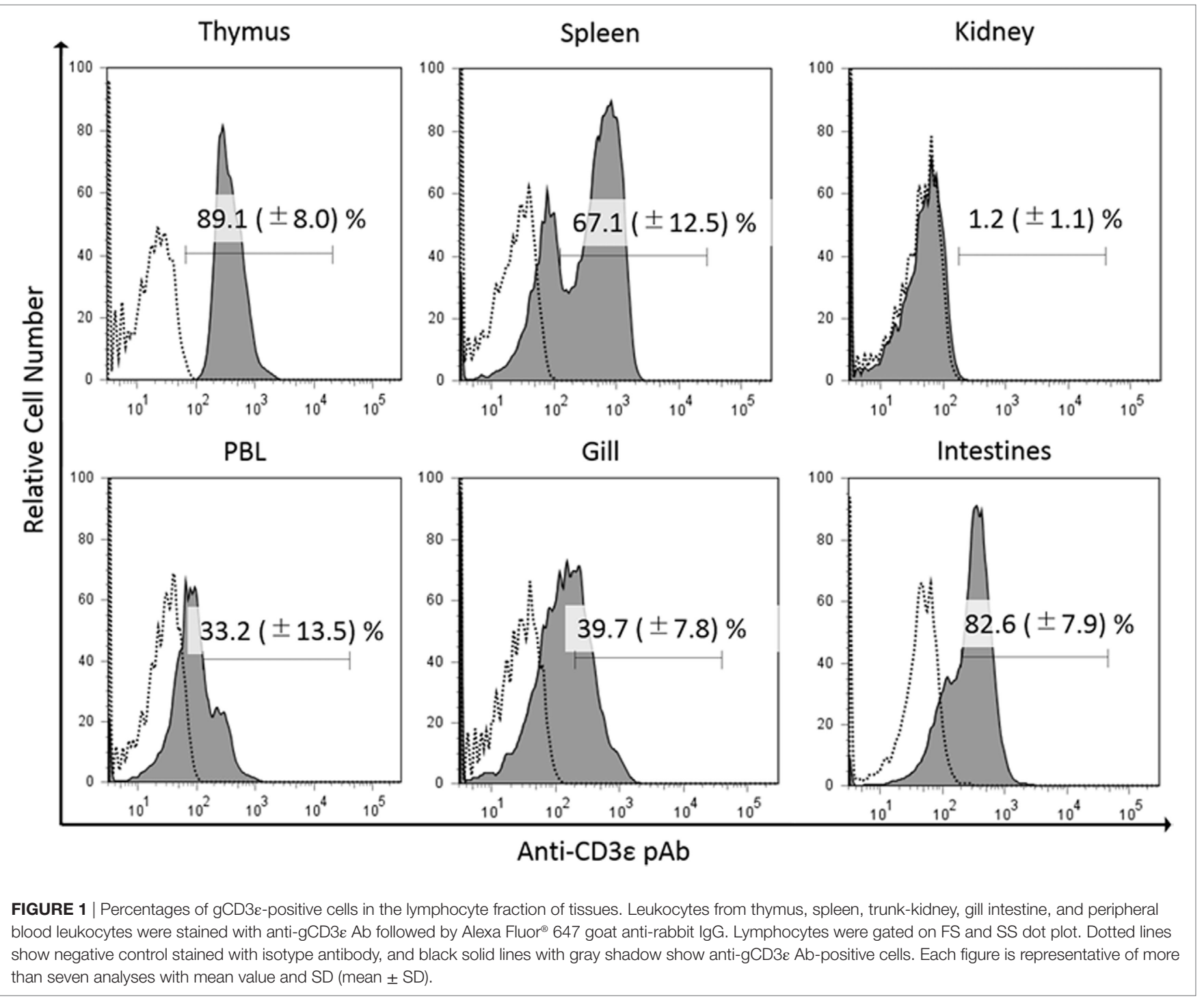

We also examined the changes of CD3 $\varepsilon$ expression after alloantigen stimulation and bacterial infection. Kidney leukocytes from fish immunized with scale allografts or infected with Edwardsiella tarda did not show the increase of CD3 $\varepsilon$ expression (Figures S8A,B in Supplementary Material).

\section{Expression of CD3 $\varepsilon$ in Migrated Kidney Lymphocytes Into Recipient Spleen}

Since we found that kidney leukocytes express CD3c protein after in vitro culture, we suspect that kidney environment suppresses the expression of $\mathrm{CD} 3 \varepsilon$ protein. We then examined the CD $3 \varepsilon$ expression of kidney leukocytes migrated into other tissues of isogeneic recipient. More than $3 \times 10^{4}$ of CFSE-positive lymphocytes were obtained and percentages of CFSE positive lymphocytes were $1.2-2.4 \%$ in kidney, spleen, and PBL of recipients fish (Figure S10 in Supplementary Material). CFSE-stained kidney leukocytes migrated into the spleen of isogeneic recipient showed the appearance of $\mathrm{CD} 3 \varepsilon$ expressing cells, while kidney cells migrated into the kidney of the recipient showed no expression (Figure 8A). Interestingly enough, CFSE-stained spleen leukocytes migrated into the kidney of the recipient failed to express CD3 $\varepsilon$, although the leukocytes express $C D 3 \varepsilon$ in the recipient spleen (Figure 8B).

\section{DISCUSSION}

In the present study, we found that all the leukocytes including CD $4-1^{+}$and CD $8 \alpha^{+}$T cells did not express CD $3 \varepsilon$ molecule in the head- and trunk-kidney, while lymphocytes from other tissues including thymus, spleen, intestine, gill, and peripheral blood expressed CD $3 \varepsilon$. However, CD4- $1^{+}$and CD8 $\alpha^{+}$T cells in the kidney expressed Zap-70 as in other tissues. Furthermore, CD4- $1^{+}$ and CD $8 \alpha^{+} \mathrm{T}$ cells in the head- and trunk-kidney become positive for the expression of CD $3 \varepsilon$ after $24 \mathrm{~h}$ in in vitro culture. Gene expression analysis revealed that $\mathrm{CD} 4-1^{+}$and $\mathrm{CD} 8 \alpha^{+} \mathrm{T}$ cells express both $c d 3 e$ and $z a p-70$ together with $l c k$ and $t c r b$, and there was no difference between kidney and spleen or between before 

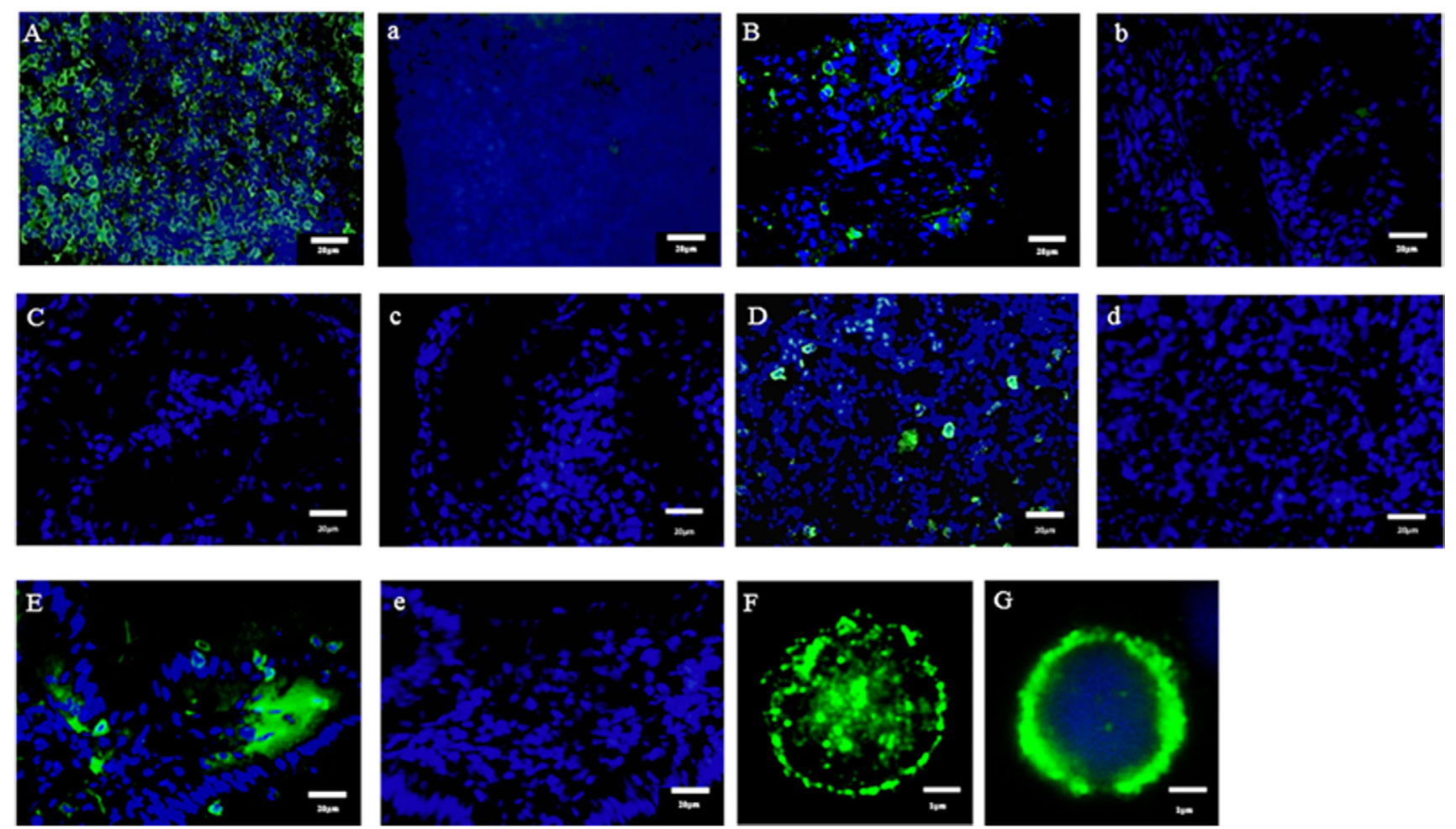

FIGURE 2 | Immuno-histochemical analysis of anti-CD3 $\varepsilon$-positive cells in tissues. Cryostat sections were stained with anti-gCD3 $\varepsilon$ Ab (A = Thymus, B = Gill, $\mathrm{C}=$ Trunk-Kidney, $\mathrm{D}=$ Spleen, and $\mathrm{E}=$ Intestine) or isotype Ab ( $\mathrm{a}=$ Thymus, $\mathrm{b}=\mathrm{Gill}, \mathrm{C}=$ Trunk-Kidney, $\mathrm{d}=\mathrm{Spleen}$, and $\mathrm{e}=$ Intestine) followed by Alexa Fluor ${ }^{\otimes}$ 488 goat anti-rabbit lgG (green). Nuclei were stained with DAPI (blue). Scale bar $=20 \mu \mathrm{m}$ (A-E). Antibody positive cells (green) were analyzed in high magnification (F). Antibody positive cell (green) were merged with nuclei staining (blue) (G). Scale bar $=1 \mu \mathrm{m}$ (F,G).

and after in vitro culture. To be interested, expression of CD3e of spleen lymphocytes was suppressed in the kidney of recipient, while kidney lymphocytes expressed CD $3 \varepsilon$ in the spleen of recipient in leukocyte transfer experiment using isogeneic fish. These results suggest that the expression of $\mathrm{CD} 3 \varepsilon$ protein, but not mRNA, is suppressed in kidney environment.

Present study revealed that $\mathrm{T}$ cell-related genes including $t c r b, c d 3 \varepsilon, z a p-70$, and $l c k$ were expressed in CD4- $1^{+}$and CD $8 \alpha^{+}$ $\mathrm{T}$ cells, while FACS analysis showed that CD3 $\varepsilon$ was neither expressed in the cytoplasm nor at cell surface of lymphocytes in the kidney. Western Blot analysis also supported the results of FACS analysis. Accordingly, these results suggest that CD3e expression is regulated at transcriptional level and CD3e is expressed at mRNA but not protein level in ginbuna kidney. It has been reported in mammals that $\mathrm{CD} 3 \varepsilon$ and $\zeta$ chains as well as TCR $\alpha$ and $\beta$ chains are essential for surface expression of TCR/ CD3 complex (1). Taken together, it is possible that TCR $\alpha$ and $\beta$ chains as well as CD3 $\varepsilon$ are not expressed on the cell surface or present in cytoplasm, although it is difficult to confirm due to the lack of antibody against TCR in fish including ginbuna. Critical role of CD3 $\varepsilon$ in TCR signaling has been extensively studied in mammals $(3,32)$. In fish, however, little is known about the role of CD3 chains in TCR signaling and transcriptional regulation of $\mathrm{CD} 3$ expression to date and further studies focusing on $\mathrm{CD} 3 \varepsilon$ is required.
To be interested, CD3 $\varepsilon$-positive cells greatly increased after $24 \mathrm{~h}$ in in vitro culture of kidney leukocytes. Furthermore, kidney lymphocytes migrated into spleen of recipient expressed CD $3 \varepsilon$ as mentioned above. These results suggest that expression of $\mathrm{CD} 3 \varepsilon$ protein in lymphocytes was suppressed in the kidney. In our study on the cytotoxicity of $\mathrm{CD} 8^{+} \mathrm{T}$ cells against allogeneic target cells, effector kidney leukocytes are required to culture in vitro for at least $8 \mathrm{~h}$ before the mixture with the target cells to induce cytotoxic activity (unpublished data). Dynamic and rapid changes in the cell surface expression of TCR/CD3 complex have been reported and the cell-surface levels of the complex present a balance among internalization, recycling, and degradation of existing complexes (33). Furthermore, impaired cell-mediated immune responses due to decreased expression of the $\mathrm{CD} 3 \zeta$ or $\mathrm{CD} 3 \varepsilon$ chain have been reported in many patients with malignant and inflammatory autoimmune diseases. For instance, downregulation of CD3ع but not $\mathrm{CD} 3 \zeta$ expression in $\mathrm{CD}^{+}$and $\mathrm{CD}^{+} \mathrm{T}$ cells has been reported in patient with lung carcinomas (9). Matsuda et al. (7) have reported the decreased expression of signal-transducing $\mathrm{CD} 3 \zeta$ chains in $\mathrm{T}$ cells from the joints and peripheral blood of rheumatoid arthritis patients. Chen et al. (8) have reported that decreased expression of both $\mathrm{CD} 3 \zeta$ and $\mathrm{CD} 3 \varepsilon$ result in an increased ex vivo susceptibility to apoptosis of peripheral blood T cells in patients with chronic myeloid leukemia. Taken 
together, it is possible that the function of T cell subsets is suppressed in ginbuna kidney environment.

Zap-70 is a part of the TCR/CD3 complex and is essential for the normal development of T cells and TCR signaling. In the present study, we found that Zap-70 was expressed as protein while CD3 $\varepsilon$ was not in kidney of ginbuna by FACS analysis. In an early event in TCR activation, Zap-70 is recruited to the TCR/ CD3 complex upon activation after the phosphorylation and activation of Lck and promotes recruitment and phosphorylation of downstream adaptor or scaffold proteins (34). Zap-70 is present as protein in the cytoplasm of $\alpha \beta$ T cells and epithelial $\gamma \delta$
T cells except for some $\gamma \delta$ T cells in peripheral lymphoid tissues (35). In contrast, dramatic and rapid changes in the expression of CD3 chains on cell surface or in cytoplasm have been reported as mentioned above. Therefore, the difference in the expression between $\mathrm{CD} 3 \varepsilon$ and Zap-70 can be attributed to the difference in the role of two molecules.

Teleost kidney is an important hematopoietic organ (36) and has morphological similarities with the bone marrow in higher vertebrates (37). The kidney also serves as a secondary lymphoid organ involved in the induction and activation of immune responses (38). In mammals, the elimination of activated $\mathrm{T}$ cells

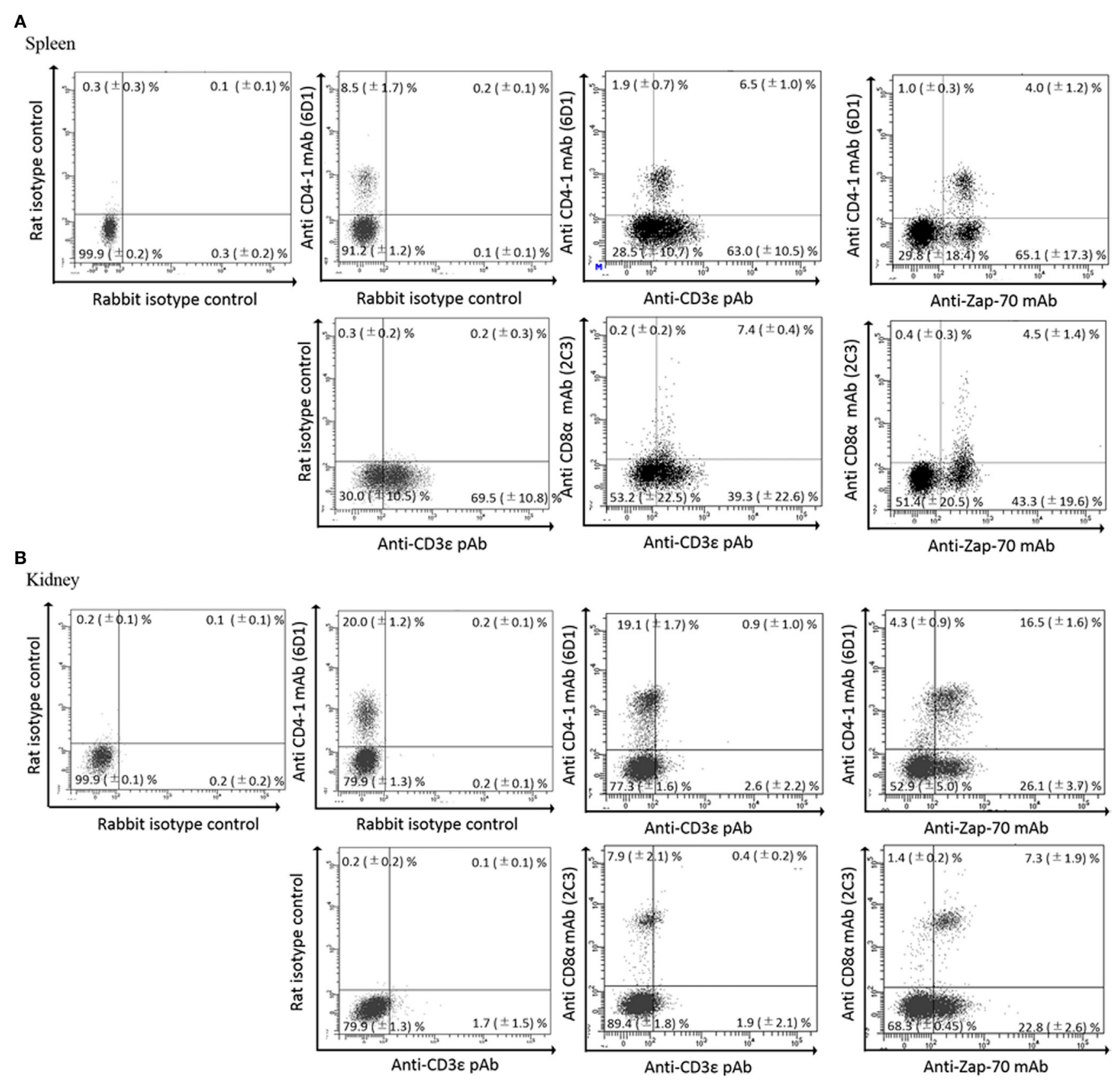

FIGURE 3 | Continued 


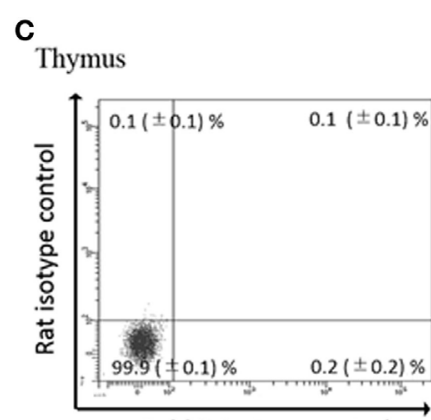

Rabbit isotype contro

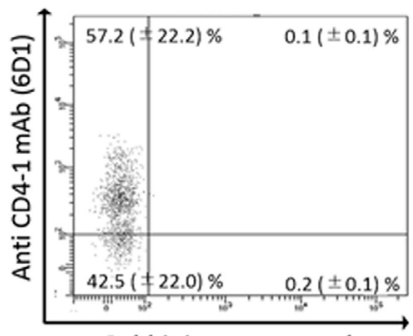

Rabbit isotype control

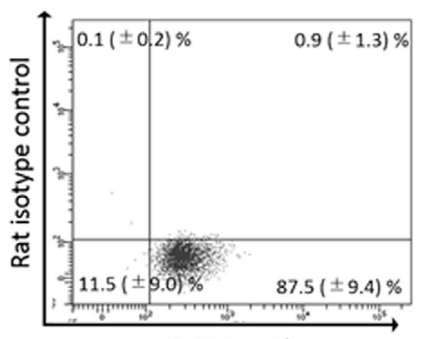

Anti-CD3 $\varepsilon$ pAb

D

PBL
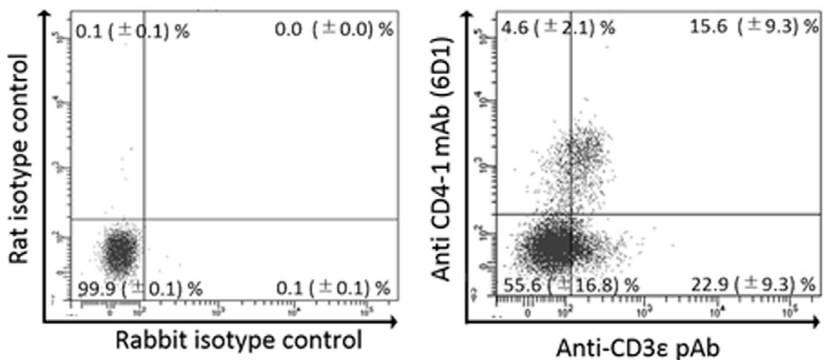

Anti-CD3 $\varepsilon$ pAb
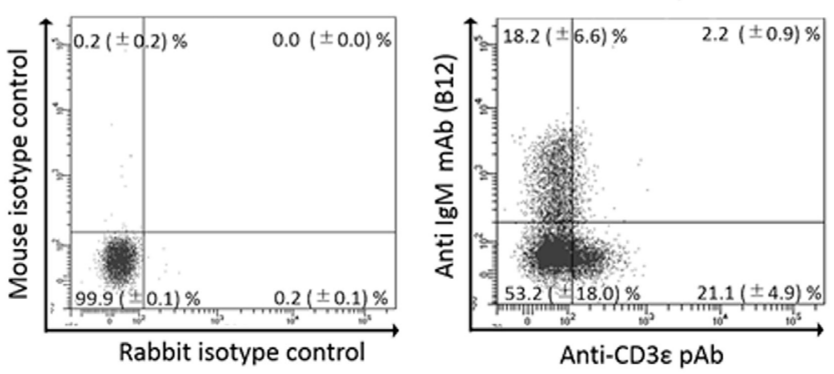

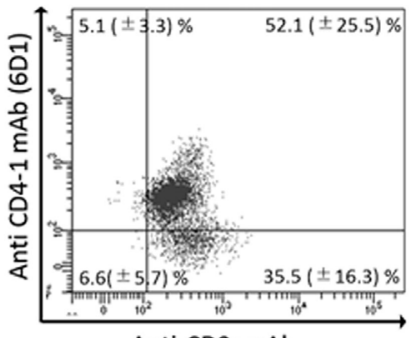

Anti-CD $3 \varepsilon \mathrm{pAb}$

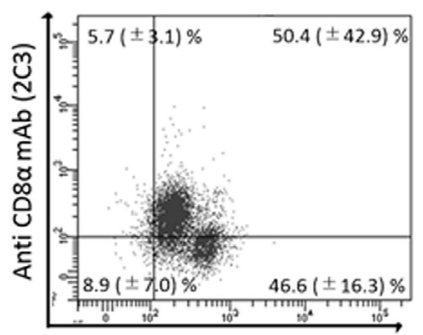

Anti-CD $3 \varepsilon$ pAb
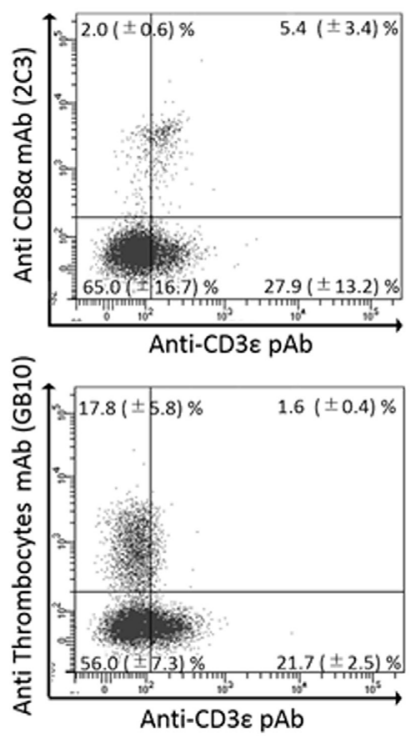
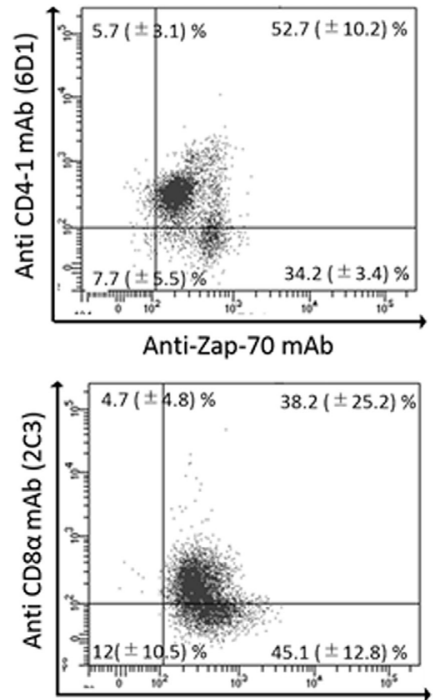

Anti-Zap-70 mAb

FIGURE 3 | Dual fluorescence analysis of CD3 $\varepsilon^{+}$, Zap-70 with lymphocyte markers in tissues. Leukocytes from spleen, kidney, and thymus were stained with the anti-CD4-1 and CD8 $\alpha$ mAbs followed by Alexa Fluor ${ }^{\circledR} 488$ anti-rat lgG, and stained with anti-gCD3e Ab or anti-hZap-70 mAb followed by 647 goat anti-rabbit lgG. (A-C) Lymphocytes were gated on FS and SS dot plot. (D) Leukocytes from peripheral blood leukocytes were stained with anti-CD4-1, CD8 $\alpha$, IgM, phagocyte, and thrombocyte mAbs, respectively, followed by Alexa Fluor ${ }^{\circledR} 488$ goat anti-rat or mouse lgG, and stained with anti-gCD3 $\varepsilon$ Ab followed by Alexa Fluor ${ }^{\circledR} 47$ goat anti-rabbit IgG. Mean \pm SD of more than three independent experiments are shown.

at the end of immune response is essential to maintain peripheral immune tolerance and avoid excessive immune responses. Resting mature T lymphocytes in the periphery start to proliferate and then undergo the activation-induced cell death via apoptosis when the $\mathrm{T}$ cells are activated by repeated stimulation of their TCR (39). Here, we hypothesize that kidney of cyprinid fish may play a role as the reservoir of resting mature $\mathrm{T}$ lymphocytes. That is, T lymphocytes in kidney are suppressed in the expression of $\mathrm{CD} 3 \varepsilon$ protein and then activated after the migration into other tissues such as spleen. This hypothesis is strongly supported by our transfer experiment of CFSE-stained lymphocytes.

Flow cytometric analysis of $\mathrm{CD} 3 \varepsilon$ protein expression in tissues has been reported in several fish species. Considerably high percentages $(10-40 \%)$ of $\mathrm{CD} 3 \varepsilon^{+}$cells were detected among total head-kidney lymphocytes of rainbow trout (40-42) and Japanese flounder (43). The percentages were similar or even higher in head-kidney rather than spleen in these species, although number of $\mathrm{CD} 3 \varepsilon^{+}$cells was relatively lower in head-kidney, spleen, 
and PBLs than that in thymus, gill, and intestine, and Western blot analysis showed that head-kidney preparations appeared negative or below the detection limit (40). Present results with the lack of CD3 $\varepsilon$ protein expression in kidney in cyprinid species do not agree with the abundant presence of $\mathrm{CD} 3 \varepsilon^{+}$cells in kidney in rainbow trout and flounder. Presence of species-specific differences in fish physiology including immune responses has been reported. For instance, ultraviolet B (UVB) irradiation markedly

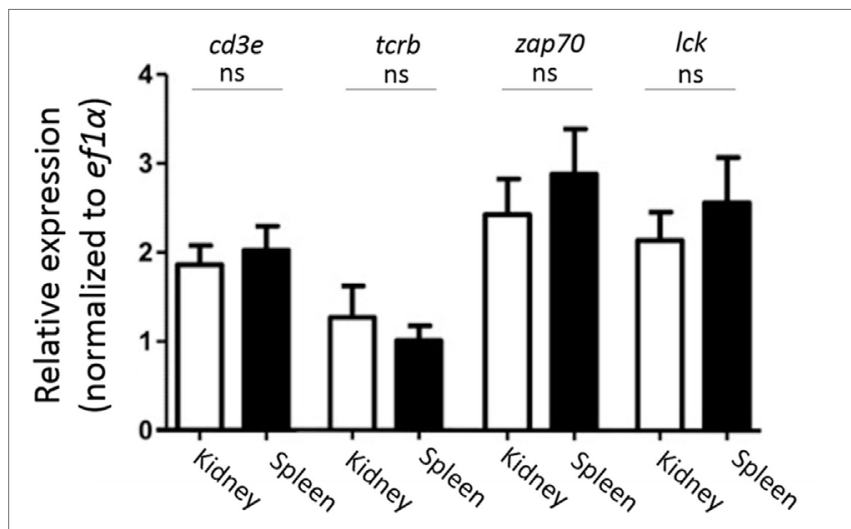

FIGURE 4 | Gene expression analysis of T cell-related genes in sorted CD4- $1^{+}$and CD8 $\alpha^{+}$lymphocytes. Trunk-kidney and spleen cells were stained with anti-CD4-1 and CD8 $\alpha$ mAbs as described in Figure 3. Lymphocytes fraction from trunk-kidney and spleen were gated on FS and SS dot plot and doublets discrimination was performed. Anti-CD4-1 and CD $8 \alpha$ mAb positive cells were sorted by FACS. Purity of FACS sorted cells was confirmed to be more than $95 \%$. Total RNA was prepared from $5 \times 10^{5}$ sorted cells and used for quantitative RT-PCR analysis. mRNA expression of cd3e, tcrb, zap-70, and lck in sorted T cells was normalized to internal control gene, ef1a. Statistical significance was calculated using $t$ tests to each gene (ns, not significant $p>0.05)$. enhanced the blood respiratory burst and cytotoxic activity in carp, although these parameters were significantly suppressed in the head kidney. In contrast, rainbow trout respiratory burst was affected only after exposure with the highest dose of UVB (44). Atlantic cod lacks the genes for CD4, MHC class II, and invariant chain involved in making and transporting MHC class II (45). However, Atlantic cod is not exceptionally susceptible to disease under natural conditions (46). Instead, Atlantic cod has a highly expanded number of MHC class I genes and unique and markedly expanded TLR genes resulting in the highest number of TLRs found in a teleost. Thus, teleost immune system is greatly diverse among species or fish groups. Accordingly, difference of $\mathrm{CD} 3 \varepsilon$ protein expression in kidney between cyprinid and other species may be attributed to the difference among species.

In the present study, we found that majority of CD4- $1^{+}$and CD8 $\alpha^{+}$lymphocytes express lower level of both CD3 $\varepsilon$ and Zap70 in the thymus, spleen, and PBL when compared to CD4-1 ${ }^{-}$, $\mathrm{CD} 8 \alpha^{-}$, and $\mathrm{CD} 3 \varepsilon^{+}$cells. We found that there are two sIgMpositive lymphocytes in the spleen and kidney of ginbuna, sIgM ${ }^{\text {low }}$ and $\operatorname{sIgM}^{\text {high }}$. In our previous study, sIgM-positive lymphocytes showed moderate non-specific cytotoxicity, while CD $8 \alpha^{+}$lymphocytes exhibited high-specific killing of allogeneic target cell lines when effector donor fish were sensitized by alloantigens (26). Furthermore, we also found that $\operatorname{sIgM}^{\text {low }}$ cells expressing granzyme and perfolin genes exhibited moderate cytotoxicity against allogeneic target cell lines, although $\operatorname{sigM}^{\text {high }}$ did not express these genes and showed no cytotoxicity suggesting that sIgM $\mathrm{M}^{\text {high }}$ cells are B lymphocytes (unpublished data). It has been reported that activated NK cells express cytoplasmic CD $3 \varepsilon$ protein in human adult and NK cell clones established from human fetal liver express $C D 3 \gamma, \delta, \varepsilon$ complexes in the cytoplasm but not cell surface (47). Similarly, Phillips et al. (48) has reported that fetal NK cells mediate cytolytic function and express cytoplasmic
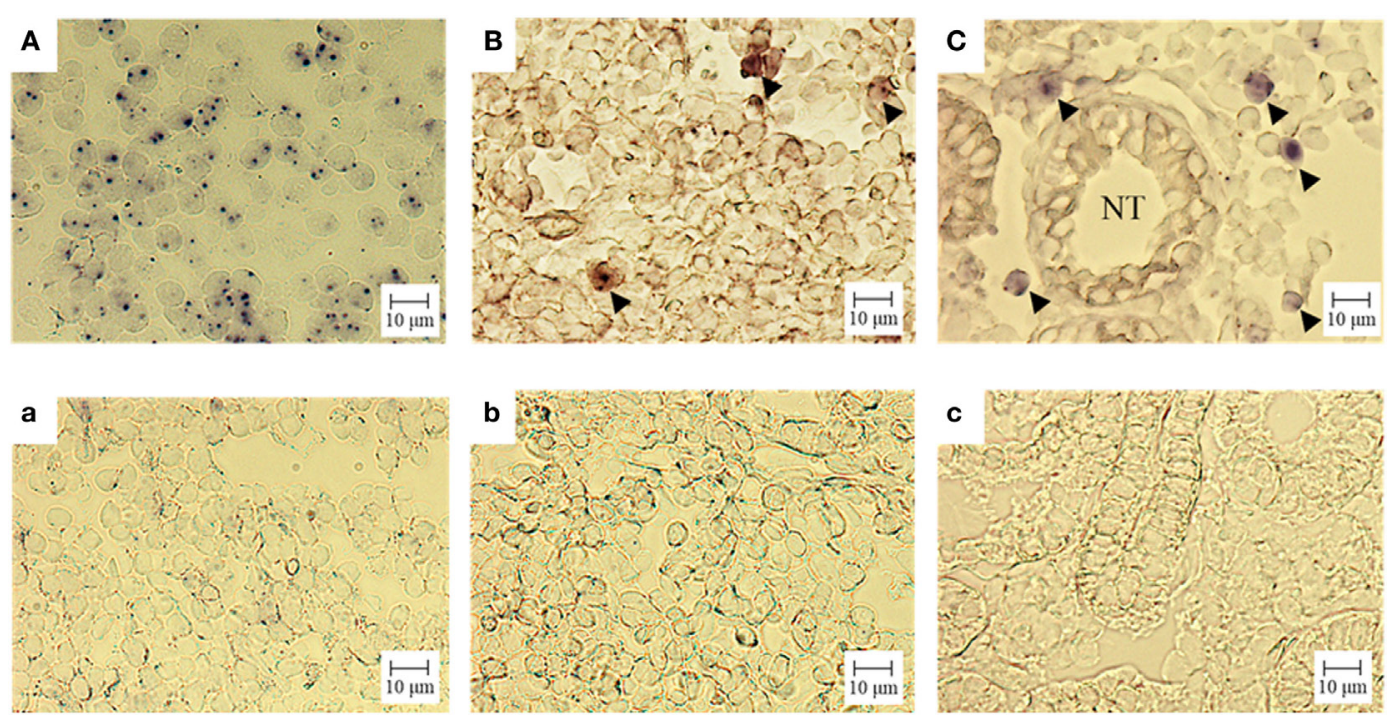

FIGURE 5 | Gene expression analysis of $C D 3 \varepsilon$ in tissue: in situ hybridization. Cryostat sections were hybridized with an antisense $(A=$ thymus, $B=$ spleen, $\mathrm{C}=$ trunk-kidney) or sense ( $\mathrm{a}=$ thymus, $\mathrm{b}=$ spleen, $\mathrm{c}=$ trunk-kidney) probe. No unspecific staining was observed (a-C). The signal of $\mathrm{CD} z \boldsymbol{\varepsilon} \mathrm{mNA}$ is observed $\mathbf{( A - C )}$. CD3e-expressing cells are indicated with arrow head (B,C). NT represents nephric tubule in $\mathbf{( C )}$ (trunk-kidney). Scale bar $=10 \mu \mathrm{m}$. 


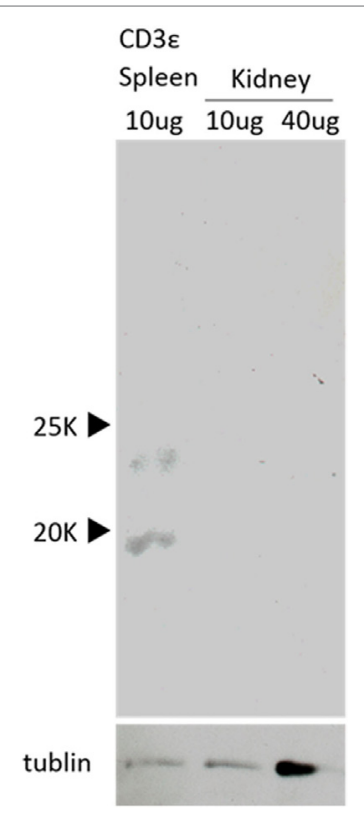

FIGURE 6 | Western Blot analysis of the presence of CD3 $\varepsilon$. Western Blot analysis with anti-CD3 $\varepsilon$ Ab of the protein samples from kidney and spleen leukocytes are shown. Both samples were normalized to tubulin (lower).
$\mathrm{CD} 3 \delta, \varepsilon$ proteins. Furthermore, it has been reported that fish NK cells also express Fc receptor (49). Taken together with previous studies, present results suggest that $s \operatorname{IgM}^{\text {low }}$ cells among $\mathrm{CD} 4-1^{-}, \mathrm{CD} 8 \alpha^{-}$, and $\mathrm{CD} 3 \varepsilon^{+}$cells are NK cells with Fc receptor.

Present study revealed that considerable numbers of $\mathrm{CD} 3 \varepsilon^{+}$ CD $4-1^{-} \mathrm{CD} 8 \alpha^{-}$cell populations (approx. 40\%) were present in spleen of carp and goldfish as well as ginbuna. It is difficult to conclude that all the populations are NK cells. Recently, lymphocyte populations involved in innate immunity have been discovered in human and mice as "innate lymphocytes," which includes NK cells and three groups of innate lymphoid cells (ILCs) $(50,51)$ and "innate-like lymphocytes" including $\gamma \delta \mathrm{T}$ cells invariant NKT (iNKT) cells and mucosal-associated invariant T (MAIT) cells (52). Intracellular expression of CD3 $\varepsilon$ has been reported in $\mathrm{CD}^{+}$ILC1 (53), and it is well known that $\gamma \delta \mathrm{T}$ cells, iNKT, and MAIT cells express CD $3 \varepsilon$ as innate T cells. Accordingly, we suspect that some of "innate lymphocytes" or "innate-like lymphocytes" are included in $\mathrm{CD} 3 \varepsilon^{+} \mathrm{CD} 4-1^{-} \mathrm{CD} 8 \alpha^{-}$cells in spleen. In fish, however, no information is available on these newly discovered lymphocyte-like populations except NK cells. Further study on lymphocyte-like populations involved in innate immunity in fish is required to solve the problem.

In conclusion, $\mathrm{CD} 4-1^{+}$and $\mathrm{CD} 8 \alpha^{+} \mathrm{T}$ cells express $\mathrm{CD} 3 \varepsilon$ mRNA but not molecule in the head- and trunk-kidney of

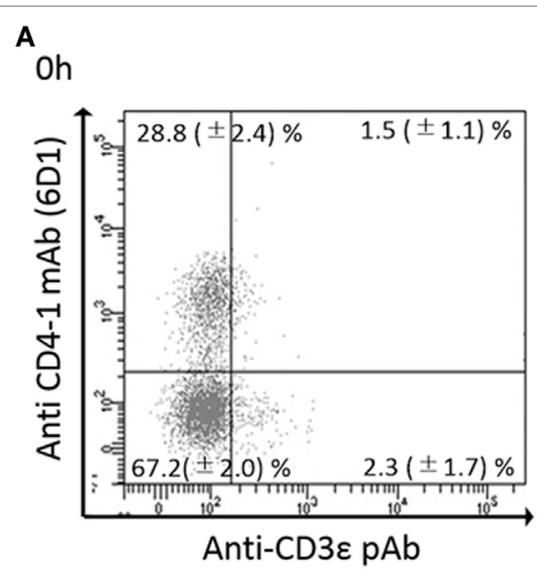

\section{$24 \mathrm{~h}$}

B

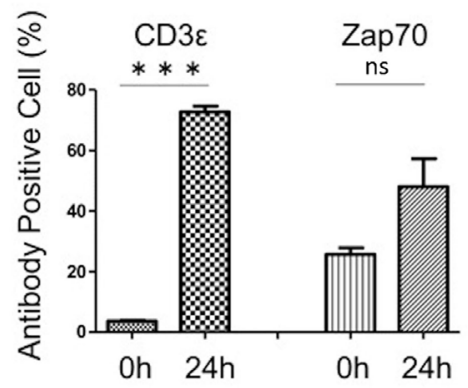

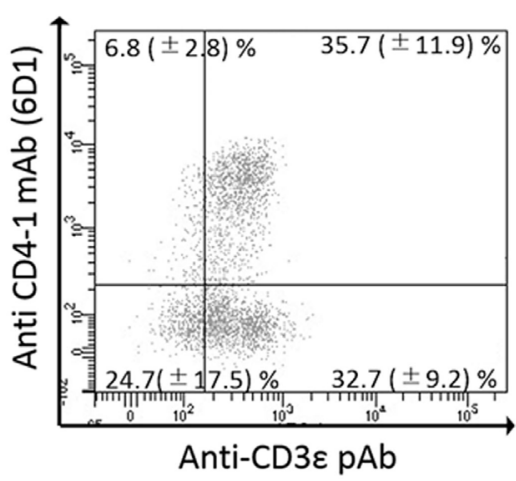

C

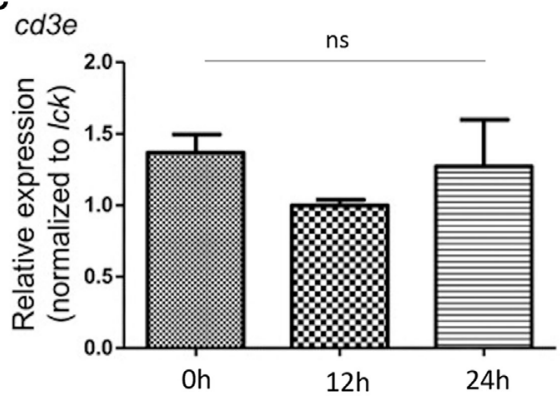

FIGURE 7 | Effects of in vitro culture on CD3e and Zap-70 expression in kidney lymphocytes. (A) Kidney leukocytes were cultured for $24 \mathrm{~h}$ and the expression of CD3 $\varepsilon$ was analyzed by FACS with more than $1 \times 10^{5}$ of lymphocytes. Mean value and \pm SD of more than three independent experiments are shown. (B) Average percentages of CD3 $\varepsilon$ and Zap-70 were calculated $\left(n=3\right.$, mean + SD). Statistical significance was calculated using $t$ tests ( $\left.{ }^{\star \star *} p<0.005\right)$ (ns, not significant $\left.p>0.05\right)$. (C) Total RNA was prepared from $2 \times 10^{6}$ cultured cells and used for quantitative RT-PCR analysis. mRNA expression of cd3e in cultured cells was normalized to T cell control gene, Ick. Average percentages of CD3 $\varepsilon$ and Zap-70 were calculated ( $n=3$, mean + SD). Statistical significance was calculated using one-way ANOVA (ns, not significant $p>0.05)$. 

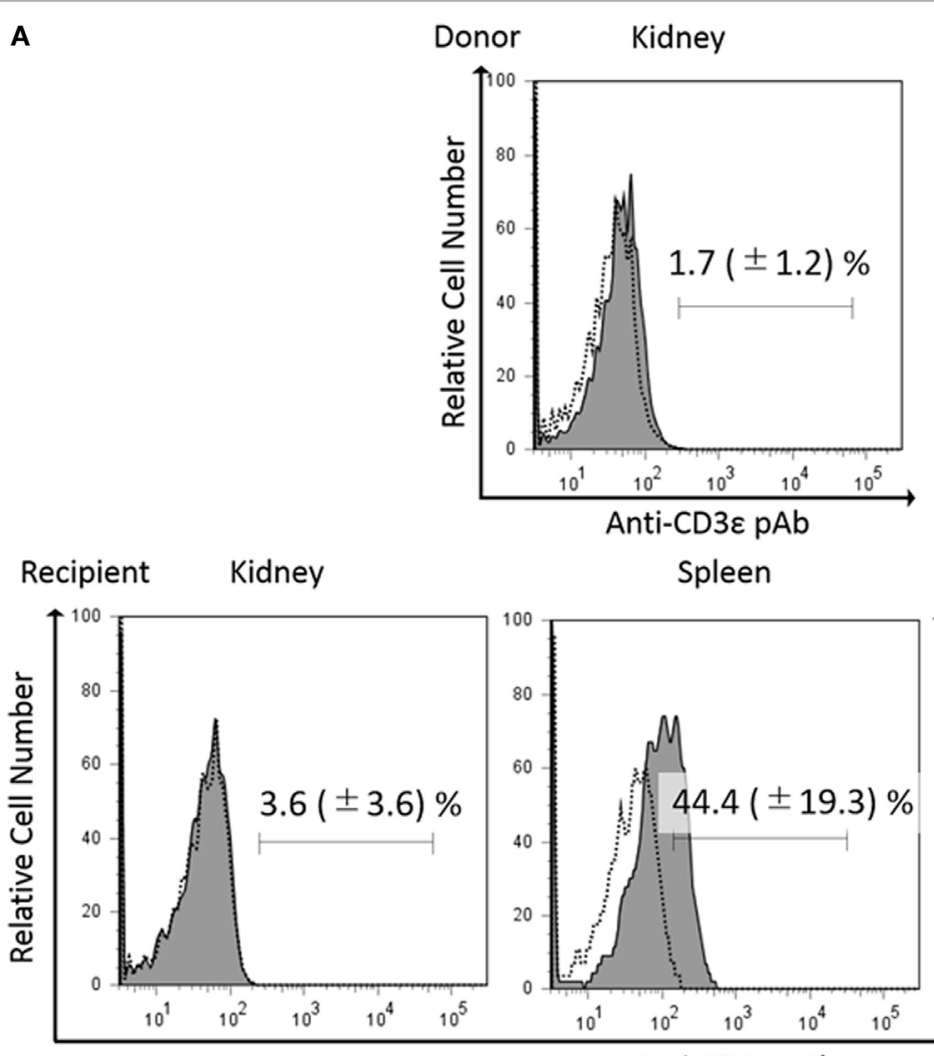

Spleen

PBL

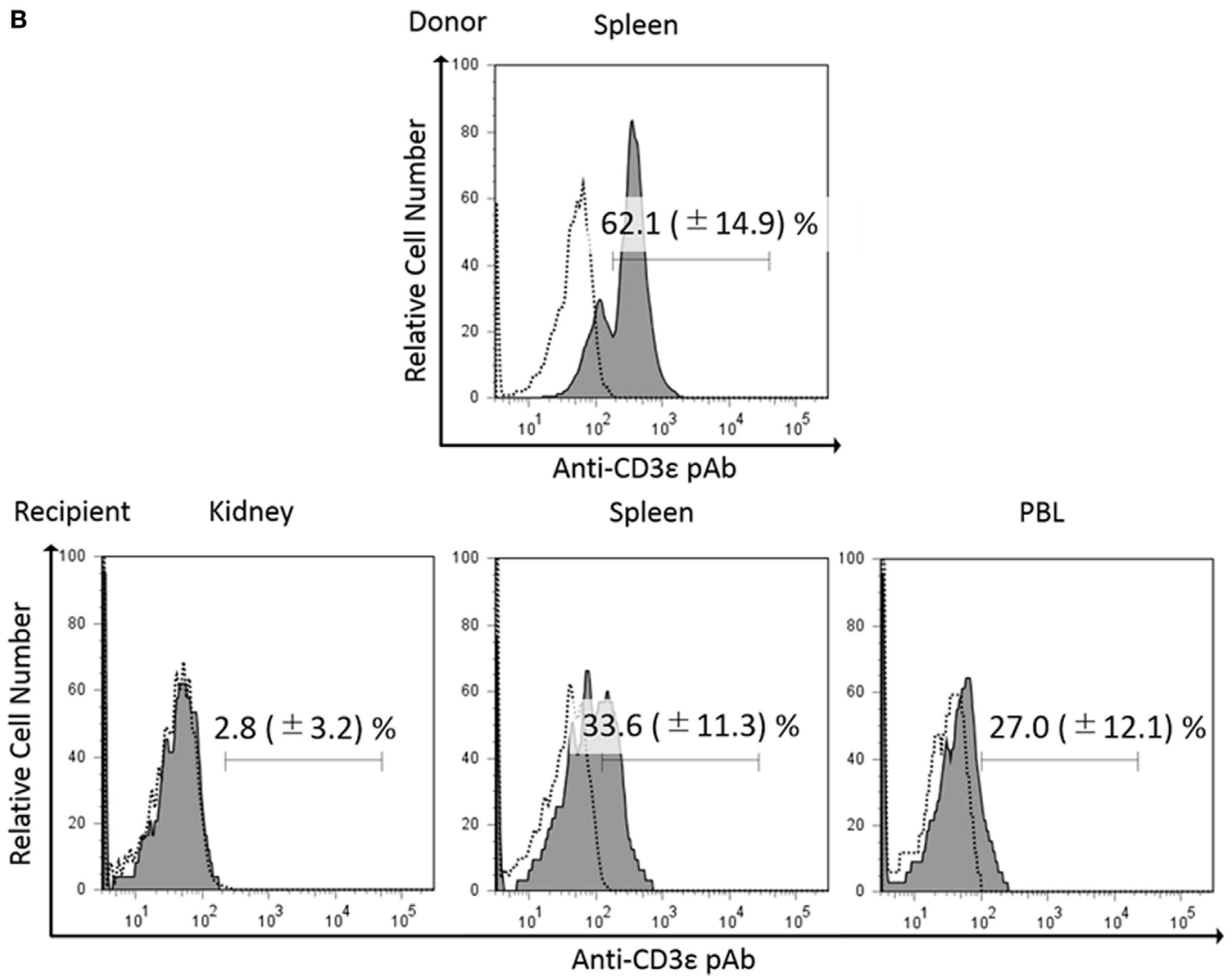

FIGURE 8 | Continued 
FIGURE 8 | Expression of CD3 $\varepsilon$ in re-injected lymphocytes in recipient tissues. Donor leukocytes were stained with CFSE, and the expression of CD3 $\varepsilon$ was analyzed by FACS before injection. Twenty four hours after injection, lymphocytes from recipient trunk-kidney, spleen, and peripheral blood leukocytes were gated on FS and SS dot plot. Histograms show the percentages of anti-CD3 $\varepsilon$ Ab and CFSE double-positive cells derived from donors. Dotted lines show negative control stained with isotype antibody and black solid lines with gray shadow show anti-gCD3ع Ab-positive cells. Mean value and \pm SD of more than three independent experiments are shown. Bars indicate gating. CFSE-labeled donor leukocytes from kidney (A) or spleen (B) were injected to the recipients.

ginbuna suggesting the lack of surface expression of TCR/CD3 complex. CD4- $1^{+}$and CD8 $\alpha^{+}$T cells in the kidney become positive for the expression of CD $3 \varepsilon$ after $24 \mathrm{~h}$ in in vitro culture and kidney lymphocytes expressed CD $3 \varepsilon$ in the spleen of recipient when transferred into other individuals belonging to the same clone. These finding indicate that expression of CD3 $\varepsilon$ was suppressed in kidney and suggest that teleost kidney plays a role as the reservoir of resting mature $\mathrm{T}$ lymphocytes, although the precise mechanism of the suppression in $\mathrm{CD} 3 \varepsilon$ expression in fish kidney remain unknown.

\section{ETHICS STATEMENT}

All of the experiments described comply with the Guidelines of Nihon University Rules concerning Animal Care and Use and have been approved by the Nihon University Animal Care and Use Committee (No. AP12B014).

\section{AUTHOR CONTRIBUTIONS}

RM and NM performed all the experimental work, with help from YM, YS, and TY. TN and RM designed the experiments and wrote the main body of the paper, with contributions from YS.

\section{FUNDING}

This work was supported in part by a Grant-in-Aid for Scientific Research (B) (Grant Number 16H04984) from Japan Society for the Promotion of Science (JSPS).

\section{SUPPLEMENTARY MATERIAL}

The Supplementary Material for this article can be found online at https://www.frontiersin.org/articles/10.3389/fimmu.2018.01321/ full\#supplementary-material.

FIGURE S1 | Ginbuna CD3 $\varepsilon$ sequence. (A) Ginbuna CD3 $\varepsilon$ sequence. Nucleotide and amino acid sequence of ginbuna $\mathrm{CD} 3 \varepsilon$ are shown. Predicted signal peptide, extracellular domain, transmembrane region, and cytoplasmic domain are labeled, CXXC motif and ITAM are boxed. Amino acid numbers are at right. (B) Schematic illustration of gCD3 $\varepsilon$. Ginbuna $C D 3 \varepsilon$ can be divided into lg-like domain, CXXC motif, transmembrane region, and ITAM. (C) Amino acid alignment of gCD3 $\varepsilon$ with Atlantic salmon (NM_001123622) and human (NM _000733.3) CD3 $\varepsilon$ sequences. The predicted signal peptide and domains are labeled. Residues similar/identical with $\mathrm{gCD} 3 \varepsilon$ are gray/black shade respectively. Ig-fold cysteine, CXXC motif and ITAM are boxed, and gaps (-) are indicated. Amino acid numbers are at right. (D) Comparison of ginbuna CD3 $\varepsilon$ with vertebrates $\mathrm{CD} 3 \varepsilon, \mathrm{CD} 3 \gamma, \mathrm{CD} 38$, and $\mathrm{CD} 3 \zeta$. Accession number of $\mathrm{CD} 3$ sequences are carp CD3 $\varepsilon$ (XM_019126514.1), takifugu (ta)CD3 $\varepsilon$

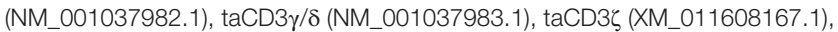

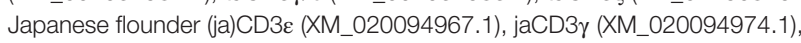

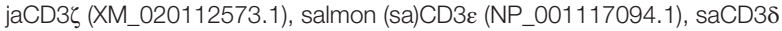

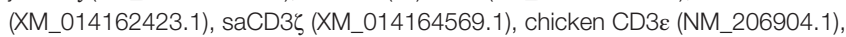

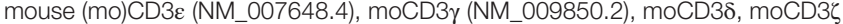

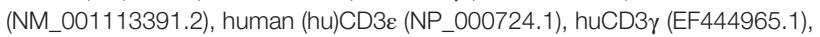

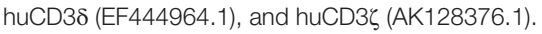

FIGURE S2 | Immuno-precipitation and Western blot analysis. After immuno-precipitation of the thymus and spleen protein samples with anti-gCD3e Ab, the proteins were detected by western blotting with anti-gCD3e Ab. Both samples show some bands around 20-25 kDa expected to be gCD3e and single band around $55 \mathrm{kDa}$ expected to be heavy-chain.

FIGURE S3 | Specificity test of rabbit serum by immune-absorption. Absorption test of $\mathrm{gCD} 3 \varepsilon \mathrm{Ab}$ was performed using transmembrane deletion mutant (TMDM) recombinant $\mathrm{gCD} 3 \varepsilon$ protein. Western blot analysis shows no band when antigCD3 $\varepsilon$ Ab was absorbed with antigen (TMDM $\operatorname{rgCD} 3 \varepsilon$, right), while the Ab not absorbed with the antigen shows positive band (left).

FIGURE S4 | Protein sequencing by LC-MS/MS. Protein sequencing was determined using a protein band reactive with anti-gCD3 $\varepsilon$ Ab detected by Western blot. LC-MS/MS revealed 28 amino acid residues (gray highlight) and $16.1 \%$ of residues matched with $\mathrm{gCD} 3 \varepsilon$ amino acid sequence (A). Mass spectrum and fragmentation tables of each amino acid fragments are shown in (B,C), respectively. Peptide sequencing is indicated by matching $\mathrm{b}$ ion (red) and y ion (blue) fragments.

FIGURE S5 | Expression analysis of CD3 $\varepsilon$ in ginbuna tissues by RT-PCR. Total RNA was prepared from peripheral blood leukocytes (PBL), thymus, head-kidney, trunk-kidney, spleen, liver, ovary, intestine, skin, and gill tissues, and used for RT-PCR analysis. ef-1a was used as an internal control. Numbers to the right indicate PCR cycles.

FIGURE S6 | Gene expression analysis of T and B cell related genes in sorted

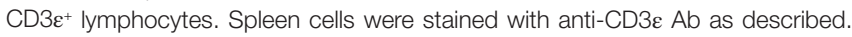
Lymphocytes fraction from spleen were gated on FS and SS dot plot and anti$\mathrm{CD} 3 \varepsilon \mathrm{Ab}$ positive cells were sorted by FACS. Total RNA was prepared from $1 \times 10^{6}$ sorted cells and used for RT-PCR analysis. mRNA expression of cd3e, cd4-, tcrb, Ick, and igm in sorted lymphocytes were shown. ef-1a was used as an internal control. Numbers to the right indicate PCR cycles.

FIGURE S7 | CD3 $\varepsilon$ expression in tissues of other cyprinid species. Spleen and kidney leukocytes from carp (A) and goldfish (B) were stained with anti-CD4-1 and CD8 $\alpha$ mAbs followed by Alexa Fluor $\AA^{8} 488$ anti-rat lgG, and stained with anti-gCD3e Ab or anti-hZAP-70 mAb followed by 647 goat anti-rabbit lgG. Lymphocytes were gated on FS and SS dot plot. Mean \pm SD of more than three independent experiments are shown.

FIGURE S8 | Modulation of CD3 $\varepsilon$ expression. After allo-antigen stimulation (A) or Edwardsiella tarda infection (B), kidney lymphocyte was stained with anti-gCD3e as described above and analyzed by FACS. Mean \pm SD of more than three independent experiments are shown. Statistical significance was calculated using $t$ tests to each gene (ns, not significant; $p>0.05$ ).

FIGURE S9 | FS and SS dot plots of kidney and spleen leukocytes. Lymphocytes, myeloid cells, and granulocytes were gated on $\mathrm{FSC}_{\text {low }}$ SSClow, $_{\text {FSChigh }} \mathrm{SSC}_{\text {low }}$, and FSC $_{\text {med }}$ SSC $_{\text {nigh }}$ population, respectively (A). Lymphocytes from kidney and spleen were gated on $\mathrm{FSC}_{\text {low }}$ SSClow population. The percentages of anti-CD3\& pAb positive cells were shown in the histogram (B).

FIGURE S10 | Migration of donor cells in recipient organs. CFSE-labeled donor cells were detected in recipient kidney, spleen, and peripheral blood leukocytes (PBL) on the histograms. Mean \pm SD of more than three independent experiments are shown.

FIGURE S11 | Effect of in vitro culture on the leukocytes composition. Before in vitro $(\mathrm{O}$ h) culture, leukocytes from kidney are composed of $46.2 \%$ of granulocytes, $11.1 \%$ of monocytes, and $39.3 \%$ of lymphocytes. Similarly, after in vitro (24 h) culture, leukocytes from kidney are composed of with $50.0 \%$ of granulocytes, $7.6 \%$ of monocytes, and $32.2 \%$ of lymphocytes. 


\section{REFERENCES}

1. Kappes DJ, Tonegawa S. Surface expression of alternative forms of the TCR/ CD3 complex. Proc Natl Acad Sci U S A (1991) 88:10619-23. doi:10.1073/ pnas.88.23.10619

2. Liu H, Rhodes M, Wiest DL, Vignali DA. On the dynamics of TCR:CD3 complex cell surface expression and downmodulation. Immunity (2000) 13:665-75. doi:10.1016/S1074-7613(00)00066-2

3. Dave VP. Hierarchial role of CD3 chains in thymocyte development. Immunol Rev (2009) 232:22-33. doi:10.1111/j.1600-065X.2009.00835.x

4. Hayes SM, Shores EW, Love PE. An architectural perspective on signaling by the pre-, $\alpha \beta$ and $\gamma \delta$ T cell receptors. Immunol Rev (2003) 191:28-37. doi:10.1034/j.1600-065X.2003.00011.x

5. Brodeur JF, Li S, da Silva Martins M, Larose L, Dave VP. Critical and multiple roles for the CD3epsilon intracytoplasmic tail in double negative to double positive thymocyte differentiation. J Immunol (2009) 182:4844-53. doi:10.4049/jimmunol.0803679

6. Ahmadi M, King JW, Xue SA, Voisine C, Holler A, Wright GP, et al. CD3 limits the efficacy of TCR gene therapy in vivo. Blood (2011) 118:3528-37. doi:10.1182/blood-2011-04-346338

7. Matsuda M, Ulfgren AK, Lenkei R, Petersson M, Ochoa AC, Lindblad S, et al. Decreased expression of signal-transducing CD3 zeta chains in T cells from the joints and peripheral blood of rheumatoid arthritis patients. Scand J Immunol (1998) 47:254-62. doi:10.1046/j.1365-3083.1998.00296.x

8. Chen X, Woiciechowsky A, Raffegerst S, Schendel D, Kolb HJ, Roskrow M. Impaired expression of the CD3-zeta chain in peripheral blood $\mathrm{T}$ cells of patients with chronic myeloid leukaemia results in an increased susceptibility to apoptosis. Br J Haematol (2000) 111:817-25. doi:10.1046/j.1365-2141.2000. 02415.x

9. Prado-Garcia H, Aguilar-Cazares D, Meneses-Flores M, Morales-Fuentes J, Lopez-Gonzalez JS. Lung carcinomas do not induce T-cell apoptosis via the Fas/Fas ligand pathway but down-regulate CD3 epsilon expression. Cancer Immunol Immunother (2008) 57:325-36. doi:10.1007/s00262-007-0372-6

10. Tang X, Qin Y, Sheng X, Xing J, Zhan W. Characterization of $\mathrm{CD}^{+} \mathrm{T}$ lymphocytes of Japanese flounder (Paralichthys olivaceus) and its response after immunization with formalin- inactivated Edwardsiella tarda. Fish Shellfish Immunol (2017) 63:220-7. doi:10.1016/j.fsi.2017.02.024

11. Araki K, Suetake H, Kikuchi K, Suzuki Y. Characterization and expression analysis of $\mathrm{CD} 3 \varepsilon$ and $\mathrm{CD} 3 \mathrm{~g} / \mathrm{d}$ in fugu, Takifugu rubripes. Immunogenetics (2005) 57:158-63. doi:10.1007/s00251-005-0772-8

12. Shang N, Sun XF, Hu W, Wang YP, Guo QL. Molecular cloning and characterization of common carp (Cyprinus carpio L.) TCR g and CD3 g/d chains. Fish Shellfish Immunol (2008) 24:412-25. doi:10.1016/j.fsi.2007.12.007

13. Øvergård AC, Hordvik I, Nerland AH, Eikeland G, Patel S. Cloning and expression analysis of Atlantic halibut (Hippoglossus hippoglossus) CD3 genes. Fish Shellfish Immunol (2009) 27:707-13. doi:10.1016/j.fsi.2009.08.011

14. Randelli E, Scapigliati G, Buonocore F. CD3g/d in sea bass (Dicentrarchus labrax): molecular characterization and expression analysis. Results Immunol (2011) 1:31-5. doi:10.1016/j.rinim.2011.08.003

15. Laing KJ, Hansen JD. Fish T cells: recent advances through genomics. Dev Comp Immunol (2011) 35:1282-95. doi:10.1016/j.dci.2011.03.004

16. Gouaillard C, Huchenq-Champagne A, Arnaud J, Chen Cl CL, Rubin B. Evolution of T cell receptor (TCR) $\alpha \beta$ heterodimer assembly with the CD3 complex. Eur J Immunol (2001) 31:3798-805. doi:10.1002/1521-4141(200112) 31:12<3798::AID-IMMU3798>3.0.CO;2-Z

17. Dave VP. Role of CD3 $\varepsilon$-mediated signaling in T-cell development and function. Crit Rev Immunol (2011) 31:73-84. doi:10.1615/CritRevImmunol.v31. i1.70

18. Press CMcL, Evensen $\varnothing$. The morphology of the immune system in teleost fishes. Fish Shellfish Immunol (1999) 9:309-18. doi:10.1006/fsim.1998.0181

19. Zapata AG, Chibá A, Varas A. Cells and tissues of the immune system of fish. In: Iwama G, Nakanishi T, editors. The Fish Immune System: Organism, Pathogen, and Environment. San Diego: Academic Press (1996). p. 1-62.

20. Kobayashi I, Moritomo T, Ototake M, Nakanishi T. Isolation of side population cells from ginbuna carp (Carassius auratus langsdorfii) kidney hematopoietic tissues. Dev Comp Immunol (2007) 31:696-707. doi:10.1016/j.dci. 2006.10.003

21. Kobayashi I, Saito K, Moritomo T, Araki K, Takizawa F, Nakanishi T. Characterization and localization of side population (SP) cells in zebrafish kidney hematopoietic tissue. Blood (2008) 111:1131-7. doi:10.1182/blood-200708-104299

22. Breart B, Bousso P. Cellular orchestration of $\mathrm{T}$ cell priming in lymph nodes. Curr Opin Immunol (2006) 18:483-90. doi:10.1016/j.coi.2006.05.006

23. Hugues S. Dynamics of dendritic cell-T cell interactions: a role in T cell outcome. Semin Immunopathol (2010) 32:227-38. doi:10.1007/s00281-010-0211-2

24. Ramiscal RR, Vinuesa CG. T-cell subsets in the germinal center. Immunol Rev (2013) 252:146-55. doi:10.1111/imr.12031

25. Livak KJ, Schmittgen TD. Analysis of relative gene expression data using real-time quantitative PCR and the $2^{-\Delta \Delta C}$ Tethod. Methods (2001) 25:402-8. doi:10.1006/meth.2001.1262

26. Toda H, Shibasaski Y, Koike T, Ohtani M, Takizawa F, Ototake M, et al. Alloantigen-specific killing is mediated by CD8-positive T cells in fish. Dev Comp Immunol (2009) 33:646-52. doi:10.1016/j.dci.2008.11.008

27. Yabu T, Toda H, Shibasaki Y, Araki K, Yamashita M, Anzai H, et al. Antiviral protection mechanisms mediated by ginbuna crucian carp interferon gamma isoforms 1 and 2 through two distinct interferon gamma receptors. J Biochem (2011) 150:635-48. doi:10.1093/jb/mvr108

28. Shibasaki Y, Matsuura Y, Toda H, Imabayashi N, Nishino T, Uzumaki K, et al. Kinetics of lymphocyte subpopulations in allogeneic grafted scales of ginbuna crucian carp. Dev Comp Immunol (2015) 52:75-80. doi:10.1016/j. dci.2015.04.013

29. Nagasawa K, Takeuchi Y, Miwa M, Higuchi K, Morita T, Mitsuboshi T, et al. cDNA cloning and expression analysis of a vasa-like gene in pacific bluefin tuna Thunnus orientalis. Fish Sci (2009) 75:71-9. doi:10.1007/s12562-008-0021-9

30. Toda H, Saito Y, Koike T, Takizawa F, Araki K, Yabu T, et al. Conservation of characteristics and functions of CD4 positive lymphocytes in a teleost fish. Dev Comp Immunol (2011) 35:650-60. doi:10.1016/j.dci.2011.01.013

31. Khallaf MA, Ogawa S, Toda H, Matsuura Y, Miyazawa R, Nakanishi T. Percentages of CD4- $1^{+}$and $\mathrm{CD} 8 \alpha^{+} \mathrm{T}$ cells in different tissues at various developmental stages in ginbuna crucian carp. Fish Pathol (2018) 53:10-8. doi:10.3147/jsfp.53.10

32. Borroto A, Abia D, Alarcón B. Crammed signaling motifs in the T-cell receptor. Immunol Lett (2014) 161:113-7. doi:10.1016/j.imlet.2014.05.007

33. Rovira-Clavé X, Angulo-Ibáñez M, Tournier C, Reina M, Espel E. Dual role of ERK5 in the regulation of $\mathrm{T}$ cell receptor expression at the $\mathrm{T}$ cell surface. J Leukoc Biol (2016) 99:143-52. doi:10.1189/jlb.2A0115-034R

34. Ngoenkam J, Schamel WW, Pongcharoen S. Selected signalling proteins recruited to the T-cell receptor-CD3 complex. Immunology (2018) 153:42-50. doi:10.1111/imm.12809

35. Kadlecek TA, van Oers NS, Lefrancois L, Olson S, Finlay D, Chu DH, et al. Differential requirements for ZAP-70 in TCR signaling and T cell development. J Immunol (1998) 161:4688-94.

36. Fänge R. Lymphoid organs in sturgeons (Acipenseridae). Vet Immunol Immunopathol (1986) 12:153-61. doi:10.1016/0165-2427(86)90119-4

37. Meseguer J, López-Ruiz A, Garcí-Ayala A. Reticulo-endothelial stroma of the head-kidney from the seawater teleost gilthead seabream (Sparus aurata L.): an ultrastructural and cytochemical study. Anat Rec (1995) 241:303-9. doi:10.1002/ar.1092410303

38. Kaattari SL, Irwin MJ. Salmonid spleen and anterior kidney harbor populations of lymphocytes with different B cell repertoires. Dev Comp Immunol (1985) 9:433-44. doi:10.1016/0145-305X(85)90006-0

39. Sikora E. Activation-induced and damage-induced cell death in aging human T cells. Mech Ageing Dev (2015) 151:85-92. doi:10.1016/j.mad.2015.03.011

40. Koppang EO, Fischer U, Moore L, Tranulis MA, Dijkstra JM, Köllner B, et al. Salmonid T cells assemble in the thymus, spleen and in novel interbranchial lymphoid tissue. J Anat (2010) 217:728-39. doi:10.1111/j. 1469-7580.2010.01305.x

41. Boardman T, Warner C, Ramirez-Gomez F, Matrisciano J, Bromage E. Characterization of an anti-rainbow trout (Oncorhynchus mykiss) CD3 $\varepsilon$ monoclonal antibody. Vet Immunol Immunopathol (2012) 145:511-5. doi:10.1016/ j.vetimm.2011.11.017

42. Maisey K, Montero R, Corripio-Miyar Y, Toro-Ascuy D, Valenzuela B, ReyesCerpa $\mathrm{S}$, et al. Isolation and characterization of salmonid CD4+ T cells. J Immunol (2016) 196:4150-63. doi:10.4049/jimmunol.1500439

43. Xing J, Ma J, Tang X, Sheng X, Zhan W. Characterizations of CD4-1, CD4-2 and CD8 $\beta$ T cell subpopulations in peripheral blood leucocytes, spleen and head kidney of Japanese flounder (Paralichthys olivaceus). Mol Immunol (2017) 85:155-65. doi:10.1016/j.molimm.2017.02.015 
44. Markkula SE, Salo MH, Rikalainen AK, Jokinen EI. Different sensitivity of carp (Cyprinus carpio) and rainbowtrout (Oncorhynchus mykiss) to the immunomodulatoryeffects of UVB irradiation. Fish Shellfish Immunol (2017) 21:70-9. doi:10.1016/j.fsi.2005.10.007

45. Star B, Nederbragt JA, Jentoft S, Grimholt U, Malmstrøm M, Gregers FT, et al. The genome sequence of Atlantic cod reveals aunique immune system. Nature (2011) 477:207-10. doi:10.1038/nature10342

46. Pilstrom L, Warp WG, Stromberg S. Why is the antibody response of Atlantic cod so poor? The search for a genetic explanation. Fish Sci (2005) 71:961-71. doi:10.1111/j.1444-2906.2005.01052.x

47. Lanier LL, Chang C, Spits H, Phillips JH. Expression of cytoplasmic CD3 epsilon proteins in activated human adult natural killer (NK) cells and CD3 gamma, delta, epsilon complexes in fetal NK cells. Implications for the relationship of NK and T lymphocytes. J Immunol (1992) 149:1876-80.

48. Phillips JH, Hori T, Nagler A, Bhat N, Spits H, Lanier LL. Ontogeny of human natural killer (NK) cells: fetal NK cells mediate cytolytic function and express cytoplasmic CD3 epsilon, delta proteins. J Exp Med (1992) 175:1055-66. doi:10.1084/jem.175.4.1055

49. Shen L, Stuge TB, Evenhuis JP, Bengtén E, Wilson M, Chinchar VG, et al. Channel catfish NK-like cells are armed with IgM via a putative FcmicroR. Dev Comp Immunol (2003) 27:699-714. doi:10.1016/S0145-305X(03)00042-9

50. Artis D, Spits H. The biology of innate lymphoid cells. Nature (2015) 517:293-301. doi:10.1038/nature14189
51. Eberl G, Colonna M, Di Santo JP, McKenzie AN. Innate lymphoid cells: a new paradigm in immunology. Science (2015) 348(6237):aaa6566. doi:10.1126/ science.aaa6566

52. Bennett MS, Round JL, Leung DT. Innate-like lymphocytes in intestinal infections. Curr Opin Infect Dis (2015) 28:457-63. doi:10.1097/QCO. 0000000000000189

53. Roan F, Stoklasek TA, Whalen E, Molitor JA, Bluestone JA, Buckner JH, et al. CD4+ group 1 innate lymphoid cells (ILC) form a functionally distinct ILC subset that is increased in systemic sclerosis. J Immunol (2016) 96:2051-62. doi:10.4049/jimmunol.1501491

Conflict of Interest Statement: The authors declare that the research was conducted in the absence of any commercial or financial relationships that could be construed as a potential conflict of interest.

Copyright (c) 2018 Miyazawa, Murata, Matsuura, Shibasaki, Yabu and Nakanishi. This is an open-access article distributed under the terms of the Creative Commons Attribution License (CC BY). The use, distribution or reproduction in other forums is permitted, provided the original author(s) and the copyright owner are credited and that the original publication in this journal is cited, in accordance with accepted academic practice. No use, distribution or reproduction is permitted which does not comply with these terms. 